\title{
REFLEXIONES JURÍDICO-CONSTITUCIONALES SOBRE LA PROHIBICIÓN DEL VELO ISLÁMICO INTEGRAL EN EUROPA
}

\author{
BENITO ALÁEZ CORRAL \\ Profesor titular de Derecho Constitucional \\ Universidad de Oviedo
}
SUMARIO
I. Delimitación del problema: cuestiones pre- vias.
II. El panorama normativo de la prohibición del velo islámico integral en Europa.
III. La prohibición del velo islámico integral en España.
IV. Análisis dogmático-constitucional de las prohibiciones del velo islámico integral en Es- paña: del velo de la intolerancia al velo de la ignorancia.

\section{DELIMITACIÓN DEL PROBLEMA: CUESTIONES PREVIAS}

A raíz de ciertos conflictos aislados que han saltado a los medios de comunicación en los últimos años, tales como la presencia en las escuelas de algunas niñas ataviadas con «Hijab» o "Chador», o la presencia en las vías públicas de algunas mujeres cubiertas con «Niqab» o «Burka», se ha reabierto en nuestro país la polémica acerca de la prohibición de ciertos símbolos religiosos ${ }^{1}$ y en particular acerca de la prohibición del velo islámico en los espacios públicos. La presentación del uso del velo islámico integral como un problema social no deja de estar vinculada en parte a la sicosis que el terrorismo islamista ha desatado en las sociedades occidentales tras los atentados del 11S, $11 \mathrm{M}$ y $7 \mathrm{~J}$, y en parte

1 Sobre lo que ya tuve ocasión de reflexionar en ALÁEZ CORRAL, B., «Símbolos religiosos y derechos fundamentales en la relación escolar», REDC, $\mathrm{n}^{\circ} 67,2003$, págs. 89 y ss. 
también —en el caso particular de España - a la reciente percepción social de choque cultural, especialmente con la cultura islámica, como consecuencia del espectacular incremento de la población inmigrante que ha experimentado nuestro país durante la primera década del siglo $\mathrm{XXI}^{2}$.

Dado el carácter paneuropeo de la cuestión, haré una breve panorámica sobre cómo encaran algunos significativos Estados miembros de la Unión Europea la prohibición del velo islámico integral en los espacios públicos, para posteriormente realizar unas breves reflexiones críticas acerca de cómo debe verse la cuestión de la prohibición del velo islámico integral desde una dogmática de los derechos fundamentales adecuada a la Constitución española de 1978. Pero, antes de comenzar, es necesario, a mi entender, precisar algunas cuestiones previas que delimitan los términos del análisis que aquí se quiere realizar, puesto que el contexto en el que se plantea la polémica de la prohibición del velo islámico integral importa, y mucho, a la hora de determinar la respuesta jurídica que se puede dar a la misma ${ }^{3}$.

En primer lugar, aunque el fenómeno y la polémica cultural abarcan más manifestaciones simbólicas del vestuario femenino, el análisis se centrará en el velo islámico integral, denominado Burka o el Niqab, que deja cubierto el rostro y hace irreconocible a la persona, sin perjuicio de que sean necesarias referencias a la prohibición del uso del velo islámico no integral, denominado Hijab o Chador, que solo cubre el cabello y el cuello, pero deja al descubierto el rostro. La razón es que el velo islámico integral es el que mejor simboliza los motivos de reproche jurídico que se han esgrimido en los distintos Estados para su prohibición, desde los más abstractos, relacionados con el llamado «orden público inmaterial», como la generación de un conflicto entre Islam y Democracia, el atentado contra los fundamentos del orden democrático-liberal occidental, entre los que están la dignidad de la mujer y la igualdad de género, la neutralidad religiosa del Estado, o la necesidad de evitar la formación de sociedades paralelas a las que conduciría el multiculturalismo, hasta los más concretos, relacionados con el orden público material, como la seguridad pública, el correcto desenvolvimiento de los servicios públicos, o la tutela de los derechos fundamentales de los demás, y en particular el derecho a la educación.

En segundo término, la prohibición a analizar se refiere al uso del velo islámico integral en los espacios públicos, lo que abarca tanto las vías públicas como los edificios pú-

2 Percepción a la que han contribuido planteamientos filosófico-políticos un tanto maniqueos como el HUNTINGTON, S. P., «The clash of civilizations?», Foreign Affairs, Vol. 72, 1993, págs. 25 y ss., que ven las civilizaciones y las identidades culturales como compartimentos estancos impermeables. Mucho más acertado es el diagnóstico de OFFE, C., «Homogenity and constitutional democracy: copying with identity conflicts through group rights», The Journal of Political Philosophy, Vol. 6, 1998, págs.121 y ss., para quien aunque el logro de cierta homogeneidad cívica en las democracias constitucionales contemporáneas presente dificultades derivadas de los conflictos de identidad entre grupos, el reconocimiento constitucional y el respeto a los derechos civiles, políticos y sociales de los individuos y de los grupos, que han servido hasta tiempos recientes para encauzar los conflictos de ideologías y de intereses, pueden servir también para canalizar los criterios conforme a los cuales se construye la identidad de esos grupos culturales o civilizaciones y para hacer funcionalmente viables los nuevos derechos de los grupos que los textos constitucionales tienden a reconocer.

3 Cfr. FRAILE ORTÍZZ, M., «The islamic headscarf: does the context matter?», InDret, nº 3, 2008, pág. 9 ss. 
blicos u otros espacios en los que se desarrollan actividades encomendadas a las administraciones públicas. Queda fuera del análisis el uso de dichas prendas en el domicilio privado, así como la posible prohibición de acceso — como consecuencia del ejercicio del denominado derecho de admisión - a un local privado de acceso público, compleja cuestión esta última relativa a la implementación de la eficacia entre terceros de los derechos fundamentales, que excede el alcance de estas reflexiones.

En tercer lugar, lo que resulta constitucionalmente problemático es la probibición del uso libre del velo integral islámico por parte de la mujer como expresión del ejercicio de sus derechos fundamentales a la propia imagen y a la libertad religiosa, sea ésta mayor o menor de edad. La prohibición de un uso coaccionado del velo islámico (integral no) no es constitucionalmente problemática, puesto que la ilicitud de la coacción, unida al mandato positivo de protección de la libertad individual que pesa sobre los poderes públicos ex art. 9.2 CE, justifican plenamente las sanciones penales y administrativas que se impongan a quienes obliguen a una mujer (mayor o menor de edad) a llevar velo islámico integral.

En cuarto lugar, aunque habitualmente se contrapongan en los medios de comunicación y en la opinión pública la prohibición del crucifijo cristiano en las paredes de los colegios públicos y la presencia del velo islámico en esos mismos colegios, la comparación es, como se verá, inapropiada. Aquí se abordará únicamente la probibición del uso del velo islámico por parte de los ciudadanos privados, es decir, el uso privado en un espacio público de un símbolo religioso, no la prohibición que, derivada del principio de aconfesionalidad del Estado, pesa sobre los poderes públicos de no revestir injustificadamente con símbolos religiosos los espacios públicos.

En quinto y último lugar, es preciso diferenciar en el análisis del panorama normativo europeo entre probibiciones generales y probibiciones parciales o sectoriales de uso del velo islámico integral en los espacios públicos. Esto tiene que ver con que las relaciones administrativas en las que se encuentra la mujer que quiere llevar el velo islámico integral pueden ser de sujeción general o de sujeción especial, es decir, tiene que ver con que el uso y disfrute del espacio público esté sometido únicamente al respeto de normas generales aplicables a la colectividad indeterminada de ciudadanos, o esté sometido a un poder público más intenso afecto a un grupo específico de ciudadanos y al cumplimiento de un determinado servicio o función pública ${ }^{4}$. Pero también está relacionado con que se trate de una ciudadana que actúa a título particular o de una empleada o funcionaria pública que pretende llevar el velo durante el cumplimiento de sus funciones públicas. Así, por ejemplo, no es idéntica la prohibición legal del velo islámico integral derivada de la necesidad de identificación en un centro escolar, sea del estudiante sea del profesor, que la prohibición general de circular por las vías públicas o de acceder a cualesquiera edificios

4 Aunque se trata de categorías (relaciones de sujeción general-relaciones de sujeción especial) que han evolucionado mucho desde su significado originario (cfr. LÓPEZ BENÍTEZ, M., Naturaleza y presupuestos constitucionales de las relaciones especiales de sujeción, Civitas, Madrid, 1994), creo que sigue siendo útil su uso para distinguir la intensidad del poder público y la intensidad de las limitaciones que pueden experimentar en ellas los derechos fundamentales, cfr. ALÁEZ CORRAL, B., «Los sujetos de los derechos fundamentales», en Francisco Bastida y otros, Teoría general de los derechos fundamentales en la Constitución Española de 1978, Tecnos, Madrid, 2004, pág. 96-98. 
públicos con un velo integral, pues como se verá, el grado se sujeción del ciudadano es distinto.

\section{EL PANORAMA NORMATIVO DE LA PROHIBICIÓN DEL VELO ISLÁMICO INTEGRAL EN EUROPA}

\section{La Unión Europea y el Consejo de Europa}

Aunque en muchos países de la Unión Europea existe un debate en torno a la prohibición del velo islámico integral, altamente mediatizado por la polémica socio-política entre multiculturalismo-asimilacionismo de la población inmigrante ${ }^{5}$, lo cierto es que la Unión Europea no ha tomado cartas en el asunto, en buena medida por la ausencia de un ámbito competencial claro sobre el que actual al respecto ${ }^{6}$. Como contrapunto hay que recordar, no obstante, que se intentó infructuosamente incluir en el Preámbulo del non-nato Tratado de Roma de 2004, por el que se establecía una Constitución para Europa, una mención a las raíces cristianas de ésta, utilizando así la referencia lingüística como expresión de la cristiandad de la Unión Europea, lo que abona la polémica antes mencionada y distorsiona en parte del debate jurídico-constitucional.

Respecto del estatuto jurídico comunitario europeo que tiene el velo islámico integral, sirve de poco el genérico reconocimiento en el art. 10.1 de la Carta de Derechos Fundamentales de la Unión Europea o en el art. 9 del Convenio Europeo sobre Derechos Humanos de «la libertad para manifestar su religión o sus convicciones individual o colectivamente, en público o en privado, a través del culto, la enseñanza, las prácticas y la observancia de los ritos» (art. 10.1 de la Carta), en la que podría quedar encuadrado su uso, pues los mismos no dicen cuáles puedan ser los límites que, introducidos por ley, constituyan «medidas necesarias, en una sociedad democrática, para la seguridad pública, la protección del orden, de la salud o de la moral públicas, o la protección de los derechos o las libertades de los demás» (art. 9 CEDH), ni si ello abarca una prohibición o no.

En el ámbito europeo, aunque fuera de la Unión, y sin eficacia jurídica vinculante, hay que mencionar la Recomendación 1927 del Consejo de Europa (Asamblea Parlamentaria), de 23 de junio de 2010, sobre «Islam, islamismo e islamofobia en Europa», que invita a los 47 Estados parte a no adoptar prohibiciones generales del velo islámico integral o de otros atuendos religiosos, puesto que las considera contrarias a la libertad religiosa garantizada por el art. 9 del CEDH cuando su uso es producto de la libre decisión de la mujer.

5 Sobre la cual, por cierto, la Unión Europea sí que ha tomado una posición común a través de los «Principios básicos comunes para una política de integración de los inmigrantes en la Unión Europea», aprobados por el Consejo europeo de Ministros de Justicia el 19 de noviembre de 2004, entre los que está considerar que la integración es un proceso bidireccional de adaptación recíproca por parte de todos los inmigrantes y residentes de los Estados miembros (principio 1), siempre bajo el respeto a los principios y valores democráticos de la Unión Europea (principio 2).

6 Únicamente cabe mencionar que el entonces Comisario Europeo de Justicia, Libertad y Seguridad, Franco Frattini se declaró en una conferencia de prensa de noviembre de 2006 desfavorable a una prohibición del Burka, puesto que ello constituiría un desincentivo a la integración de los inmigrantes de terceros Estados. 
También dentro del ámbito del Consejo de Europa, pero ya con carácter jurídicamente vinculante ${ }^{7}$, es preciso tener en cuenta para el análisis de éste problema toda una jurisprudencia del Tribunal Europeo de Derechos Humanos relativa a la libertad religiosa protegida por el art. $9 \mathrm{CEDH}$ y al uso del pañuelo o velo islámico. Entre muchas sentencias, cabe mencionar la STEDH de 15 de febrero de 2001 (Dahlab contra Suiza), la STEDH de 29 de junio de 2004 (Leyla Sahin contra Turquía) y las SSTEDH de 4 de diciembre de 2008 (Kervanci contra Francia y Dogru contra Francia), todas ellas relativas a la prohibición del uso del velo islámico en el contexto escolar; la Decisión de la Comisión Europea de Derechos Humanos, de 27 de julio de 1978 (X contra el Reino Unido), relativa a la obligatoriedad del uso del casco y la implícita prohibición de uso del turbante Sikh por los motociclistas; la Decisión de la Comisión Europea de Derechos Humanos, de 3 de mayo de 1993 (Karamandu contra Turquía), o la STEDH de 11 de enero de 2005 (Phull contra Francia), relativas respectivamente a la obligatoriedad de identificarse con la cabeza descubierta para obtener servicios administrativos como la expedición de un diploma universitario y a la obligatoriedad de descubrir la cabeza en los controles de seguridad aeroportuarios.

Sintéticamente se puede decir que esta jurisprudencia considera, en principio, el uso del velo islámico en espacios públicos como una conducta amparable por el derecho a la libertad religiosa del CEDH, siempre que sea la «efectiva expresión» de las creencias religiosas de la mujer que lo porta ${ }^{8}$; pero también considera que es susceptible de prohibición siempre que el Estado lo haga por Ley y demuestre que es una medida necesaria en una sociedad democrática para la seguridad pública, la protección del orden, de la salud o de la moral públicas, o la protección de los derechos o libertades de los demás ${ }^{9}$, sin que al hacerlo tengan un margen de apreciación sobre la legitimidad de las creencias religiosas o de su forma de manifestación ${ }^{10}$. Ahora bien, esta jurisprudencia resulta poco determinante para valorar la admisibilidad de las prohibiciones generales del velo islámico integral desde el punto de vista del art. $9 \mathrm{CEDH}$ y, por ende, desde el punto de vista constitucional español, puesto que:

7 Lo que en el caso de nuestro país implica, además, ex art. 10.2 CE ser criterio interpretativo obligatorio de la extensión de los derechos fundamentales implicados.

8 En idéntico sentido, BONCOMPAGNI, A.,, «Il velo islamico di fronte alla Corte europea dei diritti dell'uomo tra laicità e pluralismo», Rivista di studi politici internazionali, no 293, 2007, pág. 106, y Rey Martínez, Fernando, «El problema constitucional del Hijab», RGDC, n 10, 2010, pág. 3, ambos con referencia a la STEDH Sahin contra Turquía. Ciertamente, aunque se trata de una cuestión discutible, y no todo acto motivado o influenciado por una creencia o religión está amparado por el derecho a la libertad religiosa (Cfr. Decisión de la Comisión Europea de Derechos humanos de 16 de mayo de 1977 —Arrowsmith contra Reino Unido-Decisions Report Vol. 19, pág. 5), parece claro que si la mujer lo lleva porque considera que ello es la efectiva expresión (voluntaria) de las pautas o preceptos de la confesión religiosa que practica, su uso entra dentro del ámbito protegido por el art. $9 \mathrm{CEDH}$.

9 Como, por ejemplo, la neutralidad/laicidad de la educación pública (STEDH Dahlab contra Suiza, F.J. $1^{\circ}$ ), la satisfacción del derecho a la educación (SSTEDH Kervanci contra Francia y Dogru contra Francia), el derecho a la salud (DCEDH X contra Reino Unido), la protección de la seguridad pública ante la amenaza del terrorismo (STEDH Phull contra Francia), etc...

10 Tal y como ha establecido la STEDH de 26 de octubre de 2000 (Hassan y Tchaouch contra Bulgaria), FJ. 78. Sobre ello, cfr. Boncompagni, Angiolo, Il velo islamico di fronte alla Corte europea dei diritti dell'uomo tra laicità e pluralismo, ob. cit., pág. 108. 
- Se refiere hasta el momento a prohibiciones de velos no integrales, como el Chador, el Hijab, etc..., que dejan el rostro visible, no al velo islámico integral.

- Aunque se extrapolasen sus razonamientos jurídicos a la prohibición del velo integral, se trataría en todo caso de probibiciones parciales y circunscritas a contextos específicos, como el escolar, el de los controles de identidad, la protección de la salud, etc..., no de prohibiciones generales en todo espacio público, cuya necesidad en una sociedad democrática sería más difícil de justificar ${ }^{11}$.

- Por último, las prohibiciones del uso del velo islámico examinadas por el TEDH se refieren mayoritariamente a contextos en los que las mujeres que llevan el velo o el pañuelo se encontraban en una relación de sujeción especial, bien por desempeñar una función educativa (Dahlab contra Suiza), bien por encontrarse en el centro escolar en una relación educativa (Sahin contra Turquía, Kervanci contra Francia y Dogru contra Francia).

Dicho lo anterior, y ya en el ámbito de la actitud normativa de algunos Estados miembros de la Unión Europea ante la prohibición (general o parcial) del velo islámico, se pueden inducir dos tendencias una favorable y otra desfavorable a la introducción legal de una prohibición general del velo islámico integral semejante a la que se ha introducido en Francia. Dado que ambas tendencias pueden funcionar como mecanismos orientativos de la regulación de la cuestión en España, merece la pena un análisis de las mismas, por somero que sea, antes de abordar nuestro marco constitucional.

\section{Estados favorables a una probibición general}

En algunos Estados europeos, como Bélgica o Francia, se ha pasado de la prohibición particular del velo islámico (integral o no) en ciertos espacios públicos a la prohibición general del velo integral islámico en todos los espacios públicos. Y, aunque también ha habido diversas propuestas políticas (parlamentarias o gubernamentales) para introducir una prohibición general del velo integral islámico en Holanda, Noruega y Dinamarca, todavía no han fructificado legislativamente. Así, en Holanda, desde 2006 existe una propuesta parlamentaria y gubernamental para prohibir el uso del velo islámico integral en los espacios públicos, pero no ha habido el consenso y ni la decisión política suficientes como para aprobarla y ponerla en marcha. En Noruega, la Comisión de Justicia del Parlamento noruego rechazó en mayo de 2010 la propuesta del partido del progreso (liberalconservador) de prohibir el uso del velo integral islámico en los espacios públicos. Y, por último, en Dinamarca, el Primer ministro danés, M. Lars Loekke Rasmussen, declaró el 19 de enero de 2010 que el Burka y el Niqab no tenían sitio en la sociedad danesa por su forma de entender a la mujer y a la humanidad, y que se su Gobierno estaba dispuesto a discutir dentro de los límites jurídicos los medios para prohibir su uso en los espacios públicos, pero hasta el momento no se ha aprobado ninguna iniciativa parlamentaria al respecto.

11 Y la explicitud de la justificación es un elemento imprescindible para la licitud convencional de las injerencias en la libertad de manifestación de las creencias religiosas, como pone de relieve el Comité de Derechos Humanos de la ONU para el seguimiento del Pacto de Derechos Civiles y Políticos en su Comunicación CCPR/C/82/D/931/2000 (Raihon Hudoyberganova contra Uzbekistan) de 18 de enero de 2005. 
En otras palabras, solo en Bélgica y Francia, la prohibición directa o indirecta del velo islámico, circunscrita a ciertos espacios públicos en los que se desarrollan funciones públicas o ciertas relaciones administrativas de sujeción especial, se complementa ahora con una prohibición general del uso del velo islámico integral en cualquier espacio público, incluidas las vías públicas, sin necesidad de que el mismo esté sometido o afecto a un poder publico específico y más intenso. Veamos con un poco más detalle cómo regulan o pretenden regular Bélgica y Francia dicha prohibición general.

a) Bélgica

Aunque no hay estadísticas oficiales sobre cuántas mujeres llevan velo integral, según Human Rights Watcht los expertos están de acuerdo en que se trata de un fenómeno marginal entre los 400.000 musulmanes que viven en Bélgica (el $4 \%$ de la población del país $)^{12}$. A pesar de ello, después de que diversos municipios belgas de la zona flamenca regulasen por Ordenanzas municipales desde 2004 la prohibición de llevar Burka por la calle y en los edificios públicos ${ }^{13}$, con argumentos como que el Burka tiene efectos coercitivos y que no puede tolerarse que las mujeres musulmanas estén excluidas socialmente tras el Burka e imposibilitadas para comunicarse con su entorno, y después de que el Consejo de Estado belga hubiese confirmado, por Sentencia de 17 de marzo de 2009, la legalidad del Reglamento de régimen interno de un centro escolar público por el que se prohibía a los alumnos llevar dentro del mismo cualquier prenda que cubriera la cabeza o que fuese signo ostensible de pertenencia religiosa o política, lo que incluía el velo integral islámico, Bélgica se encaminó a ser el primer país de la Unión Europea que aprobase una prohibición de carácter general del velo integral islámico en los espacios públicos. Así, la Cámara de representantes del Parlamento belga aprobó el 29 de abril de 2010 un proyecto de Ley prohibitivo del uso del velo integral en espacios públicos. Sin embargo, la disolución de las Cámaras en mayo de 2010 hizo que el proyecto quedase pendiente de aprobación por el Senado. Tras la celebración de las elecciones, ambas cámaras lo retomaron y lo aprobaron con un texto casi idéntico el 1 de junio de 2011, entrando en vigor el 13 de julio con su publicación oficial en Le Moniteur Belge.

Esta Ley prevé una modificación del Código Penal que introduce penas-multa de 15 a 25 euros y/o prisión de 1 a 7 días, por la comisión de una falta (art. 563 bis CP belga) consistente en «presentarse en los espacios públicos con el rostro total o parcialmente cubierto de forma que la persona sea irreconocible». Ha desaparecido texto del finalmente aprobado la definición legal exahustiva de espacio público que contenía el proyecto caducado y que incluía ${ }^{14}$ "la vía pública, incluidos los arcenes y las aceras, los pasadizos peatonales aéreos o subterráneos, los caminos y servidumbres de paso, los parques, los jardines públicos, los campos de deporte y los parques y áreas de juego, los locales de carácter cul-

12 Cfr. http://www.hrw.org/en/news/2010/04/21/belgium-muslim-veil-ban-would-violate-rights

13 En 2009, por ejemplo, 29 mujeres fueron paradas por la policía por llevar velo integral en municipios de la región de Bruselas.

14 Véase el art. 2 de la Loi visant a interdire le port de tent retement cachant totalement ou de manière pricipale le visage, de 1 de junio de 2011 (Le Moniteur Belge 13-17-2011) 
tural abiertos al público o los edificios cerrados afectos al uso del público o en los que puedan prestarse servicios públicos» ${ }^{15}$. Aunque el proyecto de ley contempla excepciones a esta prohibición para los casos concretos previstos por los reglamentos laborales, las ordenanzas de policía o las manifestaciones festivas, lo cierto es que se trata de la prohibición legal general de uso del velo integral islámico más severa y coactiva de las propuestas hasta el momento, puesto que concibe su mero uso público como una infracción penal y permite castigar a la mujer que la comete incluso con una pena de privación de libertad.

\section{b) Francia}

Ya desde 2004, con apoyo en un entendimiento de la neutralidad religiosa «pasiva» o «distante» ${ }^{16}$, se habían aprobado en Francia prohibiciones parciales del uso del velo islámico en ciertos espacios públicos, como por ejemplo la que impone a los alumnos, en aplicación del principio de laicidad, el art. 141-5-1 del Código de la Educación (tras su modificación por la la Ley 2004-228, de 15 de marzo $)^{17}$ del uso dentro de las escuelas, colegios e institutos públicos de símbolos o de prendas que expresen ostensiblemente su pertenencia a una confesión religiosa ${ }^{18}$. Y también se habían deducido dichas prohibiciones interpretativamente de la obligación de tener la cabeza/rostro descubierto para la identificación en un control de identidad (art. 78.1 Código de Procedimiento Criminal), para la obtención de diversos documentos públicos de identidad ${ }^{19}$, para el acceso a consulados o a puntos de control de los aeropuertos ${ }^{20}$, así como para demostrar la adaptación cultural a los valores de la República francesa en el procedimiento de naturalización ${ }^{21}$. Unas y otras prohibiciones

15 Véase la Proposition de loi insérant un article 563/1 dans le Code pénal en vue d'interdire à toute personne de circuler sur la voie publique et dans les lieux publics le visage masqué, déguisé et dissimulé, actualmente en la Comisión de Justicia del Senado belga.

16 Sobre esos distintos tipos de aconfesionalidad o neutralidad, cfr. ALÁEZ CORRAL, B., Símbolos religiosos y derechos fundamentales en la relación escolar, ob. cit., págs. 101-105.

17 Una Circular del Ministerio de Educación de 18 de mayo de 2004 establece expresamente el velo islámico entre los símbolos religiosos que expresan ostensiblemente esa pertenencia a una confesión religiosa.

18 Prohibición, que es la ampliación de una prohibición indirecta que había introducido jurisprudencialmente el Consejo de Estado francés (ya desde la Sentencia de 27 de noviembre de 1989, n 346.893), al subordinar la compatibilidad de la presencia de símbolos religiosos portados por los alumnos en los centros escolares públicos con el principio de laicidad y con el cumplimiento por aquellos de sus obligaciones escolares, a que no constituyesen un acto de Presión, Provocación, Proselitismo o Propaganda; doctrina cuya convencionalidad ha sido confirmada recientemente por las SSTEDH de 4 de diciembre de 2008 (Kervanci contra Francia y Dogru contra Francia).

19 Exigencia, que el Consejo de Estado francés ha corroborado en distintas decisiones sobre el DNI, el pasaporte y el carné de conducir desde la Sentencia de 27 de Julio de 2001, n 216903, Fonds de défense des musulmans en justice; la Sentencia de 2 de Junio de 2003, $\mathrm{n}^{\circ}$ 245321, Ms R. A.; la Sentencia de 24 Octubre de 2003, $\mathrm{n}^{\circ}$ 250084, Ms B.; hasta la Sentencia de 15 de diciembre de 2006, n 289946, Association United Sikhs and M. S.

20 Sentencia del Consejo de Estado de 7 Diciembre de 2005, n 264464.

21 Deducida de la potestad que el art. 21-4 del Código Civil francés confiere al Gobierno para oponerse a la nacionalización de los inmigrantes que no demuestren adaptación a los valores de la República francesa, entre los que está la igualdad de género y el respeto a la dignidad de la persona, y que ha sido convalidada por la Sentencia del Consejo de Estado francés de 27 de junio de 2008, n 286798. 
abarcaban, sin duda, al velo integral islámico. Sin embargo, no será hasta el año 2009 cuando se plantee la aprobación de una legislación de carácter nacional que prohíba en general el uso del velo integral islámico (o cualquier otra prenda que oculte el rostro) en los espacios públicos ${ }^{22}$, que concluirá con la Ley de prohibición de ocultación del rostro en espacios públicos, de 11 de octubre de 2010. Ello, a pesar de que, según un estudio citado por la Asamblea Nacional francesa ${ }^{23}$, el fenómeno del uso del velo integral en Francia es marginal — solo 1900 mujeres de un total de entre 5-6 millones de musulmanes portan el velo integral-.

Previamente a la tramitación de la ley, el Consejo de Estado francés emitió el 25 de marzo de 2010 un Informe sobre la posibilidad jurídica de prohibir el velo integral en los espacios públicos que grosso modo ponía en duda la constitucionalidad y convencionalidad de una prohibición general de aquél, aunque admitía la posibilidad de concretas y parciales prohibiciones en ciertos espacios públicos ${ }^{24}$. En efecto, el Consejo de Estado, constata que en el sistema jurídico vigente en Francia ya existen diversas disposiciones heterogéneas que tienen como resultado prohibir el Burka, aunque sin mencionar esta palabra, para ciertas personas y en determinadas circunstancias, por motivos de orden público y que prevén sanciones penales a los instigadores de dichas prácticas. Así mismo, el Consejo de Estado señala que en los países democráticos europeos no existe una legislación nacional que prohíba de manera general el uso del velo integral islámico en los espacios públicos.

En este orden de cosas, el Consejo de Estado se cuestiona la viabilidad jurídica y práctica de una prohibición general del Burka en los espacios públicos, teniendo en cuenta los derechos y libertades garantizados en la Constitución francesa ${ }^{25}$ y en la Convención Europea de derechos humanos, y el derecho de la Unión Europea. Desde este punto de vista, considera que no es posible prohibir de forma general el Burka con base en el principio de laicidad, en tanto vestimenta portadora de unos valores incompatibles con la República, y entiende que sería muy discutible jurídicamente, tanto desde un punto de vista constitucional como desde el punto de vista de los tratados internacionales sobre derechos humanos, prohibirlo con base en la protección del orden público ${ }^{26}$. La noción de orden público material, dominante hasta el momento en la jurisprudencia administrativa y constitucional francesas, sólo permitiría prohibiciones parciales relacionadas con la concreta protección en determi-

22 Sobre cómo se gesta este proyecto de Ley entre la Asamblea Nacional y el Gobierno de la República francesa, cfr. CHELINI-PONT/FERNICHE, «L'interdiction du voile integral en France, enjeux sociaux et constitutionnels», RGDCEE, nº 24, 2010, pág. 7-12.

23 En su informe de 26 de enero de 2010 sobre la práctica del uso del velo integral en el territorio nacional (http://www.assemblee-nationale.fr/13/rap-info/i2262.asp).

24 El texto del informe está accesible en inglés y en francés en la web del Conseil d'etat. http://www.conseil-etat.fr/cde/fr/rapports-et-etudes/possibilites-juridiques-d-interdiction-du-port-du-voile-integral.html. Existe también una traducción al español de Enrique Guillén López en Videtur Quod: Anuario del pensamiento crítico, $\mathrm{N}^{\circ} .1,2009$, págs. 78-118.

25 Que, como es sabido, a diferencia de la española no contiene una propia Declaración de derechos, sino que remite a la Declaración de Derechos del Hombre y del Ciudadano de 1789 y al Preámbulo de la derogada Constitución de 1946.

26 Véase una valoración semejante del informe del Consejo de Estado en ARECES PIÑOL, M.T., «La prohibición del velo integral, Burka y Niqab: el caso francés a propósito del Informe del Consejo de Estado», RGDCEE, n 24, 2010, pág. 19. 
nados contextos de la seguridad, la tranquilidad y la salubridad públicas, mientras que la noción inmaterial de orden público conocida hasta ahora estaría vinculada a la moralidad pública y a la protección de la dignidad humana, y resultaría insuficiente como fundamento jurídico de una prohibición general. Sólo acudiendo a un entendimiento desconocido del orden público inmaterial ${ }^{27}$, que lo entienda como una base mínima de exigencias recíprocas y de garantías esenciales de la vida en sociedad (previas al texto constitucional e implícitas en el contrato social de forma permanente) que condicionan el ejercicio de otras libertades y que permiten actuar, si es necesario, contra los efectos de ciertos actos voluntarios, se podría prohibir al individuo que está en un lugar público renunciar a su pertenencia a la sociedad, o admitir que se deniegue tal pertenencia, ocultando su cara a los demás con el objetivo de impedir todo reconocimiento. Pero éste es, para el Consejo de Estado francés, un camino peligroso por la incertidumbre jurídica acerca de que tal entendimiento del orden público vaya a ser aceptado por el Consejo constitucional. Por ello, considera que en la situación jurídica actual se podría, para la protección del orden público material tradicional, adoptar una legislación más restrictiva en materia de prohibición sectorial del velo integral islámico, con base bien en que es necesaria para prevenir alteraciones del orden público altamente probables, especialmente en atención a la seguridad de bienes y de personas en ciertos espacios públicos o abiertos al público, o bien en que la lucha contra el fraude hace necesario el reconocimiento de la persona en ciertos lugares, lo que a su vez se vincula con las necesidades de funcionamiento de ciertos servicios públicos o con la aplicación de disposiciones que comportan restricciones o tratamientos diferenciados en función de la identidad o la edad.

A pesar de este Dictamen del Consejo de Estado, la Asamblea nacional y el Senado francés aprobaron la Ley 2010-1192 de 11 de octubre de 2010, que además obtuvo, antes de su formalización por el presidente de la República, el respaldo del Consejo Constitucional en su parca y apodíctica Decisión 2010-613 de 7 de octubre de 2010, en la que se dan por buenos como fundamentos de la prohibición tanto al orden público material («seguridad pública») como al novedoso entendimiento del orden público inmaterial («las exigencias mínimas de la vida en sociedad») ${ }^{28}$.

Con ese doble fundamento, explicitado en su Exposición de motivos, la Ley prohíbe el ocultamiento del rostro en los espacios públicos, con lo que, aunque su objeto sea más amplio, prohíbe el uso del velo integral islámico en espacios públicos. Concretamente, el art. 1 de la citada Ley establece que «nadie puede en el espacio público llevar una prenda dirigida a ocultar su rostro», entendiendo el art. 2.1 a estos efectos por espacio público «las vía públicas así como los lugares abiertos al público o afectos a un servicio público». Y sanciona, en el art. 3, el incumplimiento de esta obligación con mul-

27 El Senado francés, sin embargo, en su Informe de 8 de septiembre de 2010, referido al Proyecto de ley de prohibición del ocultamiento del rostro en el espacio público, pág. 16, con apoyo en las comparecencias de diversos profesores franceses de Derecho público, consideró esta noción inmaterial de orden público como implícita en la jurisprudencia constitucional, y la vinculó a conceptos como «vida familiar normal»o «valores republicanos» mencionados en Decisiones del Consejo Constitucional francés contrarias a admitir la poligamia, como la DC 93-325 o la DC 97-389.

28 Esta Decisión puede consultarse en la web del Consejo Constitucional: http://www.conseil-constitutionnel.fr/conseil-constitutionnel/francais/les-decisions/acces-par-date/decisions-depuis-1959/2010/2010-613dc/decision-n-2010-613-dc-du-07-octobre-2010.49711.html 
tas administrativas de hasta 150 euros y/o la asistencia obligatoria a clases de ciudadanía (para las mujeres inmigrantes). En el art. 2.2 de la Ley se excepcionan expresamente de la aplicación de esta prohibición los casos en los que «la prenda venga prescrita o autorizada por disposiciones legales o reglamentarias, esté justificada por razones de salud o por motivos profesionales, o se enmarque en el ámbito de actividades deportivas, festividades o manifestaciones artísticas o tradicionales», enumeración que tienen carácter exhaustivo.

\section{Estados desfavorables a una probibición general pero favorables a probibiciones parciales}

Frente al caso de Bélgica y Francia, muchos otros Estados europeos no prohíben el velo islámico integral, o, en caso de prohibirlo, lo hacen indirectamente a través de obligaciones legales de identificación para el caso de un contacto ocasional con el poder público en espacios en los que las relaciones de sujeción general permiten a los cuerpos y fuerzas de seguridad del Estado la identificación de las personas por razones de seguridad pública, investigación del delito, etc..., y directamente mediante prohibiciones de llevar símbolos o vestimentas de carácter religioso, circunscritas a ciertos espacios públicos afectos o sometidos a una relación de sujeción especial, como centros escolares, edificios administrativos, hospitales públicos, Salas de justicia, etc..., en los que el interés o servicio público justifican esa restricción de la libertad religiosa. A este modelo regulatorio pertenecen, entre otros ${ }^{29}$, Alemania, Italia o el Reino Unido, cuyas prohibiciones sobre el velo integral islámico se pasa a comentar someramente.

\section{a) Alemania}

Desde una concepción de la neutralidad religiosa del Estado «activa» o «abierta», totalmente distinta de la laicidad «pasiva» francesa ${ }^{30}$, se puede decir que las garantías iusfundamentales inherentes al orden democrático liberal fundamental que establece la Grundgesetz alemana harían inconstitucional una prohibición general del uso del velo islámico integral en los espacios públicos ${ }^{31}$, sea de ámbito nacional o de cada Estado federado. Valoración jurídica que corrobora el Servicio científico del Parlamento alemán en un Dictamen de mayo de $2010^{32}$. Por tanto, en Alemania, el espacio público es, en prin-

29 También existen prohibiciones sectoriales del uso del Burka y el Niqab en los centros escolares en Holanda.

30 Cfr. ALAEZ CORRAL, B., Símbolos religiosos y derechos fundamentales en la relación escolar, ob. cit., pág. 102.

31 Cfr. WALDHOF, Ch., Neue Religionskonflikte und staatliche Neutralität-Erfordern weltanschauliche und religiöse Entwicklungen Antworten des Staates?, GUTACHTEN D für den 68. Deutschen Juristentag, Berlín, 2010, pág. 101-102 (accesible desde la página web del autor: http://www.jura.uni-bonn.de/fileadmin/Fachbereich_Rechtswissenschaft/Einrichtungen/Institute/Kirchenrecht/WS_10_11/djt-gutachten.pdf).

32 Aunque el Dictamen no ha sido publicado, se pueden conocer algunos extractos del mismo a través del blog del diputado de la CDU Wolfgang Boschbach: http://wolfgang-bosbach.de/news/burkaverbot-indeutschland. 
cipio, un espacio en el que los ciudadanos pueden ejercer sus derechos fundamentales, incluida la manifestación de su libertad religiosa, y la neutralidad estatal a la hora de regular el uso de los mismos, más que requerir que en el mismo no haya manifestaciones de la religiosidad o de la personalidad de los ciudadanos, requiere que el mismo sea precisamente un foro público de esa pluralidad religiosa, cultural o política. Lo anterior, sin embargo, no obsta a que en ciertos espacios públicos o en ciertas relaciones con el poder público sea posible limitar el ejercicio de los derechos fundamentales implicados en el uso del velo islámico para, así, proteger derechos fundamentales de terceras personas u otros bienes o intereses de rango constitucional.

En ese sentido, desde 2003 han proliferado prohibiciones parciales (indirectas) del uso del velo islámico, incluido el integral, en el ámbito educativo, que afectan a ocho (Baden-Württenberg, Baviera, Hessen, Baja Sajonia, Sarre, Bremen, Renania del NorteWestfalia y Berlín) de los dieciséis Länder alemanes ${ }^{33}$, y están justificadas por la tutela de los derechos de los demás (a la educación, a la libertad religiosa negativa, etc...) o por la protección de bienes constitucionales (el mandato de satisfacer el derecho a la educación que pesa sobre los poderes públicos). Cinco de esos ocho Estados federados, concretamente Baden-Württenberg, Sarre, Baviera, Hessen y Renania del Norte-Westfalia, excluyen indirectamente el uso del velo islámico por parte de las maestras en los colegios públicos, en tanto en cuanto el mismo constituye una expresión de su falta de neutralidad religiosa y política, pero no excluyen igualmente el uso de símbolos religioso-culturales cristianos, como el hábito de las monjas; un diferente trato cuya constitucionalidad ha sido convalidada por la Sentencia del Tribunal Supremo Administrativo Federal, de 24 de junio de 2004.

En efecto, aunque el Tribunal Constitucional Federal alemán (Bundesverfassungsgericht) en su famosa decisión Ludin de 24 de septiembre de $2003^{34}$ estimó el amparo constitucional solicitado por la joven profesora musulmana Fehresta Ludin, admitió en los fundamentos jurídicos de la sentencia que las autoridades de los Länder pudieran establecer por Ley la prohibición de que los maestros de los colegios públicos lleven un velo islámico (concretamente un Hijab), con el argumento de que puede conllevar una falta de idoneidad para el ejercicio de la función pública en los términos dispuestos constitucionalmente ${ }^{35}$, esto es, afirmó que cabía la prohibición del velo islámico siempre que el legislador escolar del Estado federado la haya previsto y la haya justificado razonablemente en la existencia de un conflicto real (no meramente potencial) con otros intereses de rango constitucional, como el derecho a la educación de los alumnos, la libertad religiosa negativa de éstos, el derecho a educar a los hijos de los padres, o el mandato constitucional sobre los poderes públicos de proveer una educación neutral, derechos e intereses que prevalecerían.

33 Acerca de la concreta evolución legislativa escolar de los Länder alemanes sobre el velo islámico, cfr. Von Blumenthal, Julia, Das Koptuch in der Landesgesetzgebung, Nomos Verlag, Baden-Baden, 2009.

34 BVerfGE 108, 282.

35 Sobre esta sentencia, véase LASAGABASTER HERRATE, I., «El velo islámico en la jurisprudencia del Tribunal Constitucional federal alemán: nota a la STC federal alemán de 24 de septiembre de 2003», RVAP, nº. 69, 2004, pág. 235 y ss., MÜLLER-GRÜNE, S, Y MARTÍN VIDA, M.A., «¿Puede una maestra portar durante las clases en una escuela pública un pañuelo en la cabeza por motivos religiosos?: comentario a la sentencia del Tribunal Constitucional Federal Alemán de 24 de septiembre de 2003, caso Ludin», REDC, $\mathrm{n}^{\circ}$. 70, 2004, pág. 313 y ss. 
A tenor de esta jurisprudencia constitucional parece claro que el velo islámico integral, con connotaciones religiosas, culturales y político-ideológicas mucho más fuertes y claras que las del Hijab, pero sobre todo con una capacidad mucho mayor de convertirse en un elemento distorsionador, cuando no en una barrera, del proceso educativo, podría ser prohibido en el ámbito educativo tanto a los docentes como a los discentes. Para ello es necesario que así se prevea por Ley y que se fundamente en estos términos adecuadamente por el legislador. Respecto de la prohibición de uso del velo islámico integral por parte de los profesores sirven de fundamento legal las obligaciones de neutralidad y de idoneidad pedagógica establecidas por las Leyes de educación de los Estados federados, antes referidas. Y respecto de los alumnos, cabe decir que, por ejemplo, dos alumnas fueron expulsadas de una escuela pública de Bonn en 2006 por portar un Burka durante el desarrollo de las clases con apoyo en los $\$ \$ 42$ y 53 de la Ley de educación de 30 de marzo de 2004 del Land de Renania del Norte-Westfalia, que establecen la obligación para el alumnado de seguir las actividades educativas y de facilitar la consecución de los objetivos del proceso educativo establecidos en la Constitución y la propia ley educativa del Land, dado que el Burka les impedía el normal desarrollo de su propio proceso educativo y alteraba el de los demás alumnos y, con ello, el orden escolar.

Además de estas prohibiciones parciales en el ámbito educativo, existen en Alemania otras prohibiciones sectoriales del velo islámico integral, como la que se desprenden del $§ 17$ a Abs. 2 Nr. 1 de la Ley sobre el derecho de reunión y manifestación de 15 de noviembre de 1978, que prohíbe participar en reuniones en espacios abiertos al público o en manifestaciones en forma tal que se impida la acreditación de la identidad o portando objetos que impidan la acreditación de la identidad (el velo integral lo es); la que se desprende de las normas y reglamentos sobre circulación de vehículos a motor y seguridad vial que, por razones de seguridad pública, impiden conducir con Burka o Niqab, puesto que éstos limitan la capacidad de visión y de maniobra del vehículo. Por último, aunque - en contraposición a lo que recientemente ha sucedido en la Audiencia Nacional española-, el Bundesverfassungsgericht alemán ha estimado un recurso de amparo y ha considerado contraria a la libertad religiosa de la recurrente la aplicación dada al $\$ 176$ de Ley orgánica del poder judicial por un juez de menores, que prohibió a una mujer del público portar un velo islámico no integral en la Sala y la expulsó ante su negativa a quitárselo por alteración del orden ${ }^{36}$, lo cierto es que en el caso de un velo integral los mismos argumentos jurídicos dados por el Tribunal Constitucional Federal alemán en esta sentencia servirían de base para justificar la prohibición y la expulsión, en concreto el hecho de que la persona no sea identificable. Así, en el fundamento jurídico D.II.1 de la mencionada Sentencia se dispone que «en el caso concreto del uso de un velo en la Sala rige el que no se produce desacato, y con ello alteración de la sesión, si el mantenimiento del velo se debe exclusivamente a motivos religiosos y se puede excluir que, con ello, al mismo tiempo se pretenda menospreciar al tribunal o a los demás asistentes, y en tanto en cuanto la persona permanezca identificable» (la cursiva es nuestra).

36 Sentencia del Bundesverfassungsgericht de 27 de junio de 2006: http://www.bundesverfassungsgericht.de/entscheidungen/rk20060627_2bvr067705.html 


\section{b) Italia}

Partiendo de una comprensión positiva o pluralista de la laicidad prescrita por los arts. 7 y 8 de la Constitución de $1947^{37}$, tampoco parece jurídicamente posible en Italia una prohibición general del velo islámico integral en los espacios públicos. En este sentido, el Estado debe actuar como garante, y los espacios públicos deben ser un lugar para el diálogo y la coexistencia pacífica de las distintas tendencias religiosas y culturales existentes en la sociedad, así como del mantenimiento de las condiciones que hacen lo anterior posible ${ }^{38}$.

Con todo, el párrafo 26 de la Carta de valores de la ciudadanía y la integración, documento programático, jurídicamente no vinculante, presentado por el Ministerio del interior italiano el 23 de abril de 2007, dispone que «en Italia no se ponen restricciones al vestuario de las personas, con tal de que se elija libremente, y no sea perjudicial para su dignidad. No son aceptables formas de vestirse que tapen el rostro porque eso impide el reconocimiento de la persona así como entrar en relación con los demás» (la cursiva es nuestra). En este mismo sentido, dos Circulares del Ministerio del Interior italiano, una de 14 de marzo de 1995 y otra de 24 de julio de 2000, precisan, en relación con las fotografías necesarias para documentos oficiales como el DNI o los permisos de residencia, que el turbante, Chador y el velo portados por motivos religiosos son parte integrante de las vestimentas habituales y concurren en su conjunto a identificar a quienes lo portan, naturalmente siempre que se mantenga el rostro descubierto.

Más allá de lo anterior no existe una prohibición general del uso del velo integral en los espacios públicos. Sin embargo, tras diversas campañas municipales en contra del Burka, algunos Ayuntamientos italianos han intentado establecer prohibiciones generales del mismo en el ámbito municipal tomando como base legal el art. 5 de la Ley 152/1975, de 22 de mayo, de tutela del orden público, que prohíbe «el uso, sin motivo justificado, de cascos protectores o de cualquier otra prenda que haga difícil la identificación de la persona en un lugar público o abierto al público» (la cursiva es nuestra), y que hace absoluta esta prohibición en el caso de «manifestaciones que se desarrollen en lugar público o abierto al público, bajo pena de prisión de uno a dos años y de multa de 1000 a 2000 euros». Estas prohibiciones municipales han sido declaradas ilegales por diversas consideraciones legales (formales y materiales) por Sentencia de 19 de junio de 2008 del Consejo de Estado italiano. Entre los argumentos de fondo esgrimidos por el Consejo de Estado italiano en esta Sentencia aparece la interpretación del mencionado art. 5 de la Ley de 1975 en el sentido de que el ejercicio de la libertad religiosa por parte de las mujeres portadoras del Burka es un motivo justificado para cubrirse la cabeza y hacer difícil la identificación en espacios públicos, salvo en el caso de manifestaciones, en el que la prohibición para la tutela del orden público es absoluta. Además de lo anterior, el Con-

$37 \mathrm{El}$ art. 7 CI dispone que el Estado y la iglesia católica son, cada uno en su propio orden, independientes y soberanos, afirmando, con ello, la separación Iglesia-Estado; por su parte, el art. 8 CI dispone que todas las confesiones religiosas son iguales ante la ley y que la organización interna de las confesiones distintas de la Iglesia Católica es libre dentro del respeto al ordenamiento jurídico italiano, lo que supone ya una diferencia entre la Iglesia católica y las demás confesiones (cuyas relaciones con el Estado están regidas según el art. 7.2 CI por los Pactos Lateranenses).

38 Cfr. RIMOLI, F., «Laicità», Enciclopedia del Diritto, Vol. XVIII, Roma, 1955, pág. 6 
sejo de Estado añade que esta interpretación no excluye que en determinados lugares públicos o en ciertos sectores del ordenamiento jurídico se puedan prever —incluso en sede administrativa - prohibiciones del uso del velo integral islámico basadas exigencias de identificación específicas y sectoriales.

A pesar de lo anterior, en contra de lo establecido en la mencionada Sentencia del Consejo de Estado italiano, recientemente una Ordenanza del municipio piamontés de Varallo-Sesia, aprobada por un alcalde la Liga Norte, ha prohibido en 2009 el Burkini (un traje de baño islámico para las mujeres que deja descubierto solo el rostro) en los lugares públicos del municipio, bajo sanción de incautación del traje de baño y de multa de 500 euros; y otra ordenanza de 2009 del municipio de Drezzo prohíbe el uso en los lugares públicos o abiertos al público del velo islámico integral. Por último, el mismo grupo parlamentario de la Liga Norte ha depositado en el la Cámara de diputados italiana el 2 de octubre de 2010 una proposición de ley para modificar una Ley de de 1975, con el fin de prohibir el uso del Burka en espacios públicos públicos sin excepciones, es decir, sin la posibilidad de cubrirse la cabeza por motivos justificados, lo que podría plantear problemas de constitucionalidad en la medida en que la justificación consista en el ejercicio de un derechos fundamental como la libertad religiosa.

\section{c) Reino Unido}

A pesar de que en el Reino Unido, a diferencia del resto de los Estados europeos analizados hasta ahora, existe una religión oficial del Estado, la anglicana, hay también una larga tradición, enraizada tanto en documentos legales — desde la Toleration Act de 1689- como en el common law, de tolerancia hacia las minorías, que se ha ido reforzando con el tiempo a medida que se transitaba de la consideración de muchas libertades (incluida la religiosa) como libertades negativas (que exigen la no injerencia del Estado) hacia su concepción como derechos cuyo valor objetivo hace necesaria la intervención del Estado en las relaciones sociales para garantizar su adecuada protección. En consonancia con lo anterior, se puede decir, en términos generales, que no existe en el Reino Unido normativa legal que prohíba con carácter general el uso de prendas religiosas, en particular del velo islámico integral, y que las prohibiciones existentes son de carácter parcial y se han ido estableciendo en ciertos contextos, como el escolar, a partir de reglamentaciones escolares o laborales que han sido cuestionadas ante los tribunales ${ }^{39}$.

En ese sentido de tolerancia hacia los credos minoritarios, cada vez más numerosos en un país con innumerables excolonias, la House of Lords ya había decidido en 1983, en el asunto Mandla contra Dowell Lee, que la prohibición de llevar un turbante Sikh establecida por un Reglamento de un centro escolar constituía una discriminación racial, y no meramente religiosa, conforme a la Race Relations Act de 1976, dado que los Sikhs eran, además de un grupo religioso, un grupo étnico protegido especialmente por dicha ley. Esta circunstancia es considerada especialmente relevante y vuelve a ser tenida en cuenta por la Sentencia del Tribunal Superior de Justicia para Inglaterra y Gales (Queen’s

39 Sobre la cuestión de la simbología religiosa en el Reino Unido, en general, véase, GARCÍA OLIVA, J., «La cuestión de la simbología religiosa en el Reino Unido», RGDCDEE, n 15, 2007. 
Bench Division), de 29 de julio de 2008(Caso Watkins-Singh) ${ }^{40}$, que declara ilegal la prohibición de que una niña Sikh porte en un colegio una Kara (brazalete plano de acero de unos $50 \mathrm{~cm}$ de ancho, que tiene un gran significado simbólico-religioso para los Sikhs ${ }^{41}$. Ya en la primera de estas dos sentencias se exponen, en relación con la existencia o inexistencia de justificación razonable para la prohibición, las líneas maestras de la actitud de los tribunales británicos en esta cuestión: la búsqueda de una solución negociada y justificada que tenga en cuenta todo lo posible tanto los intereses de la mayoría como los de las minorías involucradas. La House of Lords afirma en el caso Mandla que entiende que «el director de la escuela tuviese grandes dificultades para explicar a un alumno no perteneciente al grupo Sikh por qué se le aplicaban a él las reglas relativas al uso de un uniforme escolar correcto y se flexibilizaban en favor del alumno Sikh», pero que, en su opinión, ello no «aportaba una justificación suficiente para una condición (la prohibición) que es prima facie discriminatoria conforme a la Ley de 1976». El Tribunal hubiese estado dispuesto a aceptar la prohibición si se hubiese justificado en que se trataba de «una escuela cristiana que aceptaba alumnos de todas las religiones y razas y que la objeción al turbante se apoyaba en que era una manifestación externa de una fe no cristiana, que en efecto se opondría a la fe cristiana», pero no fue posible porque, aunque conforme a la ley corresponde al colegio «la carga de probar que el requisito que trata de imponer está justificado en todos las circunstancias, con independencia del color, raza, nacionalidad u origen étnico o nacional de la persona a la que se le aplica», la principal justificación dada en el caso por el colegio fue que el turbante debía ser prohibido «porque es la manifestación del origen étnico del recurrente».

Por lo que se refiere ya en concreto al estatus legal del velo islámico en las escuelas, tras diversas controversias en instancias judiciales inferiores, la cuestión ha sido finalmente decidida por el Comité Judicial de la House of Lords en el caso Shabina Begum contra Headteacher and Governors of Denbigh High School. En una decisión, en la que ya era aplicable la Ley de Derechos Humanos de 1998, que transpone al ordenamiento británico la Convención Europea de Derechos Humanos, y en la que no se cuestionaba una prohibición afectante a una persona perteneciente a un grupo étnico como en los casos Mandla o Watkins-Singh, el Tribunal decide confirmar la legalidad de las disposiciones reglamentarias sobre uniformes del Instituto de Denbigh en Luton, y la consiguiente prohibición de que la alumna Shabina Begum pueda utilizar un Hijab para asistir al mismo. En opinión del Juez Lord Bingham of Cornhill, que desarrolla la opinión común de la Sala, el colegio considera que «el uniforme escolar desarrolla un papel integral en la garantía de estándares elevados y de calidad, en servir a las necesidades de una comunidad plural, promoviendo un sentido positivo de identidad común y evitando la manifestación de diferencias económicas y de moda». Para ello el Instituto ofrece

40 Sentencia de la High Court of Justice para Inglatera y Gales (Queen's Bench Division), Watkins-Singh, R (on the application of) v Aberdare Girls' High School \& Anor, [2008] EWHC 1865 (Admin)

41 Análogamente, respecto del uso por debajo de las ropas de un Kirpan (daga ritual Sikh) por parte de un niño en una escuela de Quebec, véase la Sentencia de la Corte Suprema de Canadá, de 2 de marzo de 2006, Multani v. Commission scolaire Marguerite-Bourgeoys, [2006] 1 S.C.R. 256, 2006 SCC 6; sobre ella y la comparación entre los argumentos dados en esta sentencia y en la sentencia Begum de la House of Lords británica, cfr. SAUL, B., «Wearing Thin: Restrictions on Islamic Headscarves and Other Religious Symbols», Islamic Law and Law of the muslim world research paper series at New York Law School, n ${ }^{\circ}$ 56, 2009, págs. 19 y ss. 
tres tipos de uniforme que toman en consideración aspectos culturales y religiosos presentes en la comunidad escolar, y así, permite a las chicas llevar un pañuelo en la cabeza siempre que, entre otros requisitos, deje descubierto el cuello de la camisa y la corbata (distintivos del centro escolar), a lo que se opone la forma de llevar el Hijab de Shabina Begum. En la sentencia se es consciente de la importancia fundamental de la libertad religiosa del art. $9 \mathrm{CEDH}$ para una sociedad plural y multicultural, y, aunque surge una discrepancia entre el ponente, que considera que no se ve afecta dicha libertad, y los jueces Lord Nicholls y Lady Hale of Richmond, que consideran que sí se ve afectada, la opinión común del Tribunal acepta que hay injerencia y analiza si la misma está o no justificada desde el punto de vista de la proporcionalidad siguiendo el criterio del TEDH fijado en el caso Sahin contra Turquía. De él deduce la House of Lords que el TEDH reconoce la «necesidad en algunas ocasiones de restringir la libertad de manifestar las creencias religiosas, el valor de la armonía religiosa y de la tolerancia entre grupos contrapuestos y enfrentados, el pluralismo y la apertura de mente, la necesidad de alcanzar un compromiso y un equilibrio, el papel del Estado a la hora de decidir lo que es necesario para proteger los derechos y libertades de los demás, la variedad de prácticas y de tradiciones entre los Estados miembros del Convenio, y la admisibilidad en algunos contextos de restringir el uso de prendas religiosas».Y, en consonancia con ello, no acepta las críticas de la recurrente al instituto por permitir otras modalidades de velo islámico y prohibir el Hijab, pues considera que los colegios pueden tener en el espacio y en el tiempo «diversas políticas sobre los uniformes, en atención a la composición de su alumnado y a muchas otras cuestiones». Considera, por ello, que «cada colegio debe decidir qué uniforme, si se impone alguno, sirve mejor a sus fines educativos», teniendo en cuenta la opinión los intereses de la comunidad educativa, afirmando que en el caso «el Instituto no rechazó la solicitud de la recurrente sin oírla, sino tras ello, y a la vista de que su política de uniformes se adecuaba a la opinión mayoritaria de la comunidad musulmana».

En esta misma línea, el Tribunal Superior de Justicia para Inglaterra y Gales (Queen's Bench Division) confirmó en una Sentencia de $13 / 15$ de febrero de $2007^{42}$ la legalidad de la prohibición establecida por una escuela de que una niña de 12 años musulmana no pudiese asistir llevando el velo integral, Niqab, sobre las mismas bases relativas a la autonomía de los centros para establecer reglas sobre uniformes escolares y, además, con el argumento de que el velo integral podría resultar un obstáculo para la integración escolar de la niña y para el normal desarrollo de las clases. También en relación con el velo islámico integral en el ámbito escolar, pero en este caso desde la perspectiva laboral de una profesora, el Tribunal de Apelación de Trabajo ha sostenido en una Sentencia de 30 de marzo de $2007^{43}$ que un colegio puede despedir a una profesora que pretendía usar un velo integral, Niqab, en su actividad docente. El Tribunal considera justificada la exigencia de que durante la impartición de las clases el contacto gestual y visual entre los alumnos y el profesorado refuerce la comprensión y el aprovechamiento de la actividad

42 Sentencia de la High Court of Justice para Inglaterra y Gales (Queen's Bench Division), R (on the application of X (by her father and litigation friend)) v. The Headteachers of Y School and The Governors of Y School, [2007] EWHC 298 (Admin).

43 Sentencia del Tribunal de Apelación de Trabajo, de 30 de marzo de 2007, Azmi v Kirklees Metropolitan Borough Council [2007] UKEAT 0009_07_3003. 
educativa por parte de aquéllos, en la medida en que se persigue el legítimo fin de hacer efectivo del derecho a la educación de los alumnos, y es una limitación proporcionada de la libertad religiosa de la profesora.

En unos términos similares, pero en el ámbito institucional de la colaboración con el ejercicio de la función jurisdiccional, según informaciones periodísticas ${ }^{44}$, un juez inglés de inmigración habría prohibido a una abogada ataviada con Niqab defender a su cliente en su Sala, precisamente porque el velo impediría al juez oírla adecuadamente y, por tanto, satisfacer el ejercicio del derecho de defensa del cliente.

\section{LA PROHIBICIÓN DEL VELO ISLÁMICO INTEGRAL EN ESPAÑA}

En la España aconfesional instaurada con la Constitución de 1978, cuya neutralidad religiosa del Estado no equivale, a tenor de la jurisprudencia constitucional ${ }^{45}$, a la laicidad pasiva o distante francesa, sino más bien a una neutralidad activa o positiva como la alemana ${ }^{46}$, el espacio público es, en principio, un ámbito en el que las personas pueden ejercer individual o colectivamente sus derechos fundamentales, y no está presidido por ninguna obligación de neutralidad garantizada por el Estado, a salvo de las limitaciones que dichos derechos fundamentales puedan experimentar conforme a lo prescrito en la propia Constitución o en las leyes limitadoras de los derechos. En este sentido, ni la Ley orgánica $7 / 1980$, de 5 de julio, de libertad religiosa (LOLR) vigente, ni ninguna otra disposición legal, han previsto hasta el momento explícitamente una prohibición general de llevar el velo islámico (integral o no) en los espacios públicos, probablemente porque, más allá de la polémica mediática, el uso del velo islámico integral parece claramente minoritario y casi anecdótico. Es más, aunque el Senado aprobó el 23 de junio de 2010 una proposición no de Ley, a iniciativa del Grupo Popular, instando al Gobierno a

44 Cfr. New York Times. http://www.nytimes.com/2007/06/22/world/europe/22veil.html?_r=2\&oref=

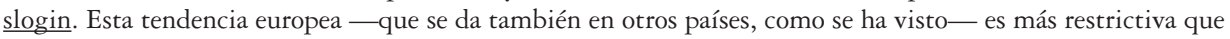
la que adoptan los tribunales estadounidenses, tal y como pone de relieve ALLEN, A. L, "Veiled women in the american Courtroom: Is the Niqab a barrier to justice?» Penn Law. Public law and legal theory research papers series, $\mathrm{n}^{\circ} 25,2010$, págs. 1 ss.

45 Una de las últimas sentencias en recordarlo es la STC 38/2007, de 15 de febrero de 2007, FJ $5^{\circ}$, sobre la potestad eclesiástica de condicionar la renovación de los contratos de los profesores de religión católica de los centros públicos.

46 Cfr. Aláez Corral, B., Símbolos religiosos y derechos fundamentales en la relación escolar, ob. cit., pág. 105. No se pretende que esa interpretación del principio de aconfesionalidad, que ha realizado el Tribunal Constitucional ya desde sus primeros años, sea la mejor interpretación, sino simplemente afirmar que normativamente es la última vinculante, solo superable con una reforma constitucional, es decir, con un cambio en las reglas interpretadas, pues el Tribunal Constitucional, en una Constitución democrática abierta como la nuestra, no tiene atribuida una competencia para sustituir el juicio interpretativo constitucionalmente válido del legislador por el suyo, aunque este último sea mejor; en un sentido semejante, cfr. NAVARRO VALLS, R.,, «Neutralidad activa y laicidad positiva. (Observaciones a «Para una interpretación laica de la Constitución», del profesor A. RUÍZ MIGUEL)», RGDCDEE, nº18, 2008, pág. 3; en un sentido diverso, proponiendo prescriptivamente una interpretación más laicista de la aconfesionalidad prescrita por la CE de 1978, cfr. Ruíz Miguel, Alfonso, «La neutralidad, por activa y por pasiva. (Acotaciones al margen de «Neutralidad activa y laicidad positiva», del profesor Rafael Navarro Valls)», RGDCDEE, n¹8, 2008, págs. 2-3 y ss. 
establecer una prohibición general nacional del Burka en espacios públicos ${ }^{47}$, el Congreso de los Diputados rechazó casi un mes después, en julio de 2010, una propuesta semejante del mismo partido político ${ }^{48}$, y el Parlamento de Cataluña también había rechazado pocos días antes idéntica prohibición general para su Comunidad Autónoma ${ }^{49}$.

No obstante, para solucionar muchos de los conflictos surgidos a raíz del incremento de la población inmigrante existente en nuestro país y, consiguientemente, de la pluralidad religiosa y cultural, se ha echado mano del argumentario legal existente para deducir interpretativamente de diversos textos legales y reglamentarios sectoriales, sobre todo en materia educativa, prohibiciones implícitas del uso del velo islámico (integral o no) en ciertas relaciones sociales y en ciertos espacios públicos, aunque en la mayoría de los casos las normas legales aplicadas no se refiriesen explícitamente a modalidad alguna del velo islámico.

Así, por ejemplo, en el año 2010 el Instituto público de enseñanza secundaria de Pozuelo de Alarcón en aplicación de su Reglamento de régimen interno, cuyo cumplimiento es conforme al art. 6.4.g) de la Ley orgánica 8/1985 de 3 de julio, reguladora del derecho a la educación (LODE) obligado para los alumnos, no permitió a una niña musulmana asistir a clase con un $\mathrm{Hijab}^{50}$, caso que ya tenía su antecedente conocido en otra prohibición semejante impuesta en 2004 a otra niña de origen magrebí en otro centro escolar público madrileño. Aún no se conoce resolución judicial para el primer caso y en otros — como el segundo- que no se impugnan judicialmente la solución suele pasar por el cambio de centro escolar o por la flexibilización del criterio del centro y la admisión de la alumna.

Igualmente, en el ámbito judicial, el 23 de septiembre de 2009 el juez Javier Gómez Bermúdez solicitó que se ausentase de su Sala de la Audiencia Nacional una testigo que se negó a atestiguar sin el Burka, con base en la imposibilidad de valorar la veracidad de su testimonio. Y el 29 de octubre de ese mismo año, en un asunto que contrasta con el resuelto por la Sentencia del Bundesverfassungsgericht alemán de 27 de junio de 2006, la abogada Zoubida Barik Edidi, de origen marroquí y nacionalidad española, estando en los estrados de una Sala de vistas de la Audiencia Nacional revestida con toga y con un Hijab, fue expulsada por el mencionado juez, al negarse a quitarse el velo islámico, con base en una polémica interpretación dada por él, en ejercicio de su policía de estrados, del art. 37.1 del Estatuto de la Abogacía y del art. 33 del Reglamento de Honores, Tratamiento y protocolo en la Actos judiciales solemnes ${ }^{51}$. El asunto fue recurrido adminis-

47 DSS, de 23 de junio de 2010.

48 DSCD, de 20 de julio de 2010.

49 DSPC de 01 de julio de 2010.

50 Conforme al art. 32.c)4. del citado Reglamento de régimen interior, de 30 de octubre de 2007: «Los alumnos deberán acudir a clase correctamente vestidos, con objeto de evitar distracciones a sus compañeros. En el interior del edificio no se permitirá el uso de gorras ni de ninguna otra prenda que cubra la cabeza».

51 El art. 37.1 del Real Decreto 658/2001, de 22 de junio, por el que se aprueba el Estatuto de la Abogacía dispone que «Los abogados comparecerán ante los Tribunales vistiendo toga y, potestativamente, birrete, sin distintivo de ninguna clase, salvo el colegial, y adecuarán su indumentaria a la dignidad y prestigio de la toga que visten y al respeto a la Justicia». Y el art. 33 del Reglamento 2/2005, de 23 de noviembre, de Honores, Tratamiento y protocolo en la Actos judiciales solemnes, establece que «...Fiscales, Secretarios, Abogados del Estado, Abogados y Procuradores en actos solemnes judiciales y actos jurisdiccionales que tengan lugar en los estrados, usarán toga y, en su caso, placa y medalla. En todo acto jurisdiccional llevarán traje o vestimenta acorde con la solemnidad del acto». 
trativamente por la abogada ante el Consejo General del Poder Judicial que archivó el asunto por no observar infracción disciplinaria del juez, y ante la Sala de lo Contencioso Administrativo del Tribunal Supremo que desestimó el recurso por motivos formales, sin entrar en el fondo del asunto, al considerar que el acto del juez Bermúdez era un acto jurisdiccional (del orden penal) y no un acto administrativo, por lo que debería haberse impugnado por los cauces jurisdiccionales previstos en la Ley de Enjuiciamiento Criminal ${ }^{52}$.

En el ámbito administrativo, al igual que sucede en Francia o en Italia, también se puede deducir una implícita prohibición de uso del velo integral de la obligación impuesta por el Real Decreto 896/2003, de 11 de julio, por el que se regula la expedición del pasaporte ordinario y se regulan sus características, y por el Real Decreto 196/1976, de 6 de febrero, por el que se regula el Documento Nacional de Identidad, de que se utilicen fotografías del «rostro del solicitante, tamaño carné, en color y con fondo claro, liso y uniforme, tomada de frente, y sin gafas de cristales oscuros o cualquier otra prenda que impida la identificación de la persona».

Pero lo que quizás haya suscitado más polémica ha sido la aprobación por parte de diversos Ayuntamientos catalanes de ordenanzas municipales que introducen de forma expresa prohibiciones parciales al uso del velo integral islámico. Tal es el caso de Lleida, Reus, Barcelona, Tarragona y otros ${ }^{53}$. Respecto de los términos concretos de la prohibición se observan tres características comunes al contenido de estas nuevas normas municipales:

- no se trata de una prohibición general de su uso en las vías públicas, sino parcial para el acceso a los edificios o instalaciones municipales;

- no se circunscribe solo al velo integral islámico sino a cualquier prenda o vestimenta que impida la identificación de la persona, motivo justificador de las prohibiciones;

- se anuda la imposición de una sanción pecuniaria y/o inhabilitadora a la contravención de las mencionadas prohibiciones.

En concreto, por ejemplo, la nueva Ordenanza de civismo del Ayuntamiento de Lleida proscribe, con una finalidad preventiva desde el punto de vista de la seguridad y la identificación de los usuarios de los servicios municipales, acceder a los edificios e instalaciones municipales usando Burka, Niqab, casco o pasamontañas que impidan su identificación, bajo multa de entre 30 y 600 euros. Y, por su parte, el Pleno del Ayuntamiento de Reus aprobó el 22 de diciembre de 2010 una modificación de la Ordenanza municipal sobre el uso de las vías y los espacios públicos, por la que se prohíbe acceder y permanecer en instalaciones municipales a las personas que lleven velos integrales, pasamontañas, casco integral y otros accesorios que impidan su identificación, bajo multa de hasta 750 euros, y aunque la misma está aún en período de alegaciones, su aprobación definitiva es más que previsible.

Precisamente, estas últimas prohibiciones municipales son las que han vuelto a poner sobre la mesa con su máxima intensidad el debate acerca de la constitucionalidad de la prohibición del velo islámico integral que aquí se aborda, y a cuyas líneas maestras dogmático-constitucionales dedicaremos el último epígrafe de este trabajo.

52 STS de 2 de noviembre de 2010 (Sala de lo Contencioso administrativo), FJ. $7^{\circ}$.

53 CAÑAMARES, ARRIBA, S., «Nuevos desarrollos en materia de simbología religiosa», RGDC$D E E, \mathrm{n}^{\circ} 24,2010$, pág. 4 enumera un elenco de ellos bastante numeroso tanto en Cataluña como en otras Comunidades Autónomas. 


\section{ANÁLISIS DOGMÁTICO-CONSTITUCIONAL DE LAS PROHIBICIONES DEL VELO ISLÁMICO INTEGRAL EN ESPAÑA}

Una valoración crítico-constitucional de las regulaciones españolas sobre la prohibición del velo islámico, y en particular del velo integral, no se puede realizar a partir de la precomprensión filosófico-política que cada intérprete (doctrinal o jurisprudencial) tenga de las prescripciones constitucionales sobre valores superiores como la libertad, la igualdad o el pluralismo, sobre principios como el de aconfesionalidad, o sobre la dignidad de la personas y los derechos fundamentales que permiten realizarla. Muy al contrario, es preciso y posible realizarla a partir de una interpretación, dogmáticamente adecuada al texto de la CE de 1978, del objeto contenido y límites de los derechos fundamentales que se hallan en juego con el uso del velo integral islámico ${ }^{54}$. Me centraré, pues, en el análisis dogmático-constitucional de las prohibiciones que se pretenden establecer o se han establecido en España, aunque muchas de las reflexiones sean extrapolables a Estados — especialmente de la Europa continental— que comparten con nosotros bastantes principios y valores constitucionales y, sobre todo, algunos elementos de la configuración constitucional de los derechos fundamentales.

Sin pretender juzgar la oportunidad política de las prohibiciones parciales (ya aprobadas en algunos municipios) o generales (infructuosamente propuestas) del uso del velo islámico integral en los espacios públicos, sino únicamente su adecuación al abierto marco constitucional, sí que se observa en la opinión pública una cierta inclinación social a ignorar las condiciones democráticas que los textos constitucionales imponen al ejercicio del poder limitativo de los derechos fundamentales, y a identificar la democracia con la regla de la mayoría, y no con el gobierno de la mayoría dentro del respeto a la minoría, que es modelo de democracia implantado por la Constitución Española de 1978. Así, se daría la paradoja de que se imputa al velo islámico integral el ser la expresión de una cultura o religión intolerante e irrespetuosa con la libertad e igualdad de la mujer, pero al mismo tiempo se corre el tupido velo de la ignorancia precisamente sobre la libertad de las mujeres que usan el velo integral para ejercer sus derechos fundamentales (allí donde no se pueda probar que su uso es coaccionado), desconociendo las condiciones constitucional-democráticas de la limitación de los derechos fundamentales. Esta inclinación autoritaria de la mayoría social se manifiesta en diversos polos argumentales, alguno de los cuales están presentes en la fundamentación jurídica de las prohibiciones del velo islámico que hemos visto en los distintos países europeos: primero, en la confusión entre lo que pueden hacer los ciudadanos y lo que pueden hacer los poderes públicos; segundo, en la idea de que la voluntad social, expresada a través de los órganos representativos o administrativos, puede limitar los derechos fundamentales de la persona en beneficio de cualquier interés general de la sociedad, incluso aunque no tenga plasmación textual en la Constitución; tercero, en la pretensión de construir la dignidad de la mujer, como un límite al uso del velo islámico integral, al margen de la voluntad libremente expresada de ésta a partir de la ilegítima superposición de la interpretación que da la mayoría social de un acto personal

54 Cfr. BASTIDA FREIJEDO, F., «La interpretación de los derechos fundamentales», en BASTIDA y otros (edit.), Teoría general de los derechos fundamentales en la Constitución española de 1978, Tecnos, Madrid, 2004, págs. 77-82.

UNED. Teoría y Realidad Constitucional, núm. 28, 2011, pp. 483-520. 
respecto del cual no se ha probado objetivamente que sea más dañino para la sociedad que para la mujer que voluntariamente lo realiza. Veamos críticamente cada uno de ellos.

\section{La diferente consideración de los símbolos religiosos según los utilicen ciudadanos o poderes públicos}

Comparar, como se ha hecho, la retirada del crucifijo de las paredes de los centros escolares públicos ${ }^{55}$ o del Salón de Plenos de un Ayuntamiento ${ }^{56}$, con el hecho de que un alumno o un profesor lleven un símbolo religioso como un velo islámico, es mezclar dos situaciones completamente distintas, no tanto por el carácter estático y dinámico de uno y otro símbolo ${ }^{57}$. Cuanto por la distinta naturaleza y legitimidad de unos y otros para usarlo. El crucifijo en las aulas lo coloca o permite que permanezca en ellas un poder público, la administración educativa, de la que forman parte los Consejos escolares que, como el del colegio Macías Picavea de Valladolid, deciden de forma parcialmente ilegal autorizar su presencia, es decir, un ente con capacidad para imponer obligaciones unilateralmente, un sujeto que solo excepcionalmente puede disfrutar de derechos fundamentales ${ }^{58}$. El velo islámico sobre la cabeza del alumno o del profesor, lo portan ciudadanos, carentes, en principio, de poder legal para imponer unilateralmente obligaciones por sí mismos y que disfrutan de una libertad garantizada constitucionalmente con uno o varios derechos fundamentales (libertad religiosa, propia imagen), sin perjuicio de que, al llevar dichas prendas o símbolos, especialmente en espacios públicos como la escuela, estén sometidos a límites. Aunque algunos de ellos, los profesores, puedan tener la obligación de neutralidad religiosa e ideológica en el desempeño de su función docente, no han de ser neutrales en la faceta personal de su vida, que no desaparece con su ejercicio de funciones docentes, pero que debe modularse, como se vera después, en todo aquello en lo que sea incompatible con el correcto desenvolvimiento de ese servicio público y

55 Ordenada judicialmente en nuestro país respecto del Colegio público «Macías Picavea» de Valladolid, por la Sentencia del Tribunal Superior de Justicia de Castilla y León (Sala de los Contencioso-Administrativo), de 14 de diciembre de 2009. En el ámbito europeo, en una sentencia referida a Italia, la STEDH, de 3 de noviembre de 2009 (Lautsi contra Italia), también ha confirmado la necesidad de dicha retirada del crucifijo por conculcar la neutralidad religiosa del Estado, aunque la Gran Sala de este Tribunal la ha revocado recientemente en su STEDH de 18 de marzo de 2011, confirmando la licitud convencional de la decisión de las autoridades italianas de no ordenar dicha retirada. En Alemania, por su parte, el Bundesverfassungsgericht ya había acordado en 1995 (BVerfGE 93, 1) la inconstitucionalidad de los crucifijos en las aulas escolares públicas, al menos, sin restricciones, obligando a las autoridades de los Länder a su regulación detallada con respeto a la libertad religiosa negativa de los alumnos y de los padres.

56 La pretensión de la Asociación «Movimiento hacia un Estado laico» de que se retirase un crucifijo del Salón de Plenos del Ayuntamiento de Zaragoza ha sido, no obstante, rechazada en primera instancia por la Sentencia del Juzgado de lo Contencioso-Administrativo de Zaragoza, de 30 de abril de 2010.

57 Sobre esta sentencia cfr. ALAEZ CORRAL, ÁLVAREZ ÁLVAREZ, Las decisiones básicas del Tribunal Constitucional Federal alemán en las encrucijadas del cambio de milenio, CEPC, 2008, pp. 944-977. Como la diferenciación que lleva a cabo CAÑAMARES ARRIBA, S., «Nuevos desarrollos en materia de simbología religiosa», ob. cit., pág. 2-11.

58 Cfr. ALAEZ CORRAL, B., «Los sujetos de los derechos fundamentales», en Bastida y otros, Teoría general de los derechos fundamentales en la Constitución española de 1978, ob. cit., págs. 89-90. 
con la satisfacción del derecho a la educación de los alumnos. Y en el caso de los alumnos, sus derechos fundamentales se ven igualmente modulados en el interior de los centros escolares por la satisfacción de su derecho/deber a la educación y el derecho/deber a la educación de los demás alumnos.

En este sentido, aunque en España rija el principio de «aconfesionalidad positiva», la posibilidad de que los poderes públicos cooperen con las confesiones religiosas no supone alterar la prohibición de que aquéllos, como regla general, no pueden interferir en las esferas de libertad de los individuos sino en los casos constitucionalmente permitidos; mientras que los ciudadanos, por el contrario, como regla general pueden actuar libremente, y solo excepcionalmente podrán ver limitadas sus esferas de libertad cuando la Ley, de conformidad con la Constitución, así lo haya previsto. No se puede describir, por tanto, el problema como un presunto «choque de civilizaciones» que se resuelve, como en Francia, con una suma cero: la neutralidad del espacio público, puesto que las posiciones iusfundamentales de unos y otros actores son distintas: ni se trata de que los poderes públicos de los Estados europeos adornen los espacios públicos tanto con símbolos cristianos como con símbolos islámicos, ni tampoco de impedir a los alumnos o profesores portar símbolos cristianos o islámicos en un espacio público, como el educativo, que ha de ser un foro en el que precisamente con una finalidad educativa se ejerciten los derechos fundamentales, pues es la mejor manera de realizar el ideario educativo constitucional previsto en el art. 27.2 CE: la educación en valores y principios democráticos y en el respeto a los derechos fundamentales ${ }^{59}$.

2. La libertad religiosa y/o el derecho a la propia imagen como derechos limitables por una prohibición del uso del velo integral islámico

\section{a) El uso del velo islámico integral como parte del objeto de los derechos a la libertad religiosa y a la propia imagen}

Íntimamente vinculado a la diferenciación anterior entre poderes públicos y ciudadanos se encuentra el segundo polo argumental que condiciona jurídicamente la prohibición del velo islámico integral en los espacios públicos: la trascendencia iusfundamental de la conducta consistente en portar un velo islámico en un espacio público. Por lo pronto, hay que reiterar que cubrirse la cabeza con un velo islámico en el espacio público por motivaciones religiosas constituye, a tenor de la jurisprudencia europea $^{60}$, una manifestación del ejercicio del derecho a la libertad religiosa, pues encaja dentro del objeto de ella. Pero, además, en la medida en que se trata de un acto de configuración de la apariencia exterior de la propia figura humana, también es expresión del derecho a la propia imagen ${ }^{61}$. Ambos derechos fundamentales están directa-

59 Sobre el mismo, cfr. ya la STC 1981, de 13 de febrero, FJ $7^{\circ}$, así como el voto particular del magistrado Francisco Tomás y Valiente que fue el que acuñó el término «ideario educativo de la Constitución».

60 STEDH de 29 de junio de 2004 (Leyla Sahin contra Turquía), párr. 71 y 78.

61 En un sentido similar, CUERDA RIEZU, A., «El velo islámico y el derecho a la propia imagen «, Parlamento y Constitución, $\mathrm{n}^{\circ}$ 11, 2008, págs. 247-256; sin embargo, en contra abiertamente, PASCUAL MEDRANO, A., El Derecho fundamental a la propia Imagen. Fundamento, Contenido, Titularidad y Limites, ThomsonAranzadi, Cizur Menor, 2003, pág. 63. 
mente garantizados por la Constitución de 1978, sin que se requiera ningún desarrollo legal expreso para su disfrute. ¡Parece mentira que, tras 32 años de vigencia de nuestra Constitución, todavía haya que trasladar a la opinión pública esta idea de la eficacia directa de las normas constitucionales y en particular de las que garantizan derechos fundamentales, que parecen estar en vigor sólo cuando los ejerce la mayoría social culturalmente homogénea!

Que el uso en público del velo islámico forme parte del objeto de uno u otro derecho fundamental, o de ambos a un tiempo, dependerá, sobre todo, del significado que se le atribuya como símbolo. En mi opinión, la polémica acerca de si el velo islámico es un símbolo religioso o cultural se ha de resolver en principio a favor de su carácter religioso, puesto que, sea cual sea la concepción — subjetiva u objetiva- que se mantenga de símbolo religioso, lo cierto es que muchas de las mujeres que lo portan, así como la propia sociedad occidental que se ve confrontada con ellas, lo asocian como práctica con la confesión religiosa islámica, algunas de cuyas corrientes deducen su uso de los versículos 24:31 y 33:59 del Corán ${ }^{62}$. Pero, tanto si se le atribuye un significado religioso y es manifestación de las convicciones religiosas de la mujer que lo porta, como si se le atribuye simplemente un significado identitario-cultural y no es más que expresión de la configuración que la mujer quiere dar a su apariencia exterior, la conducta consistente en llevar velo islámico estaría abstractamente protegida por el derecho fundamental a la propia imagen. En efecto, aunque la jurisprudencia constitucional apenas se haya ocupado hasta el momento de esta faceta del objeto del derecho a la propia imagen, y se haya centrado en la facultad de disponer sobre la representación gráfica de la figura humana más que en la configuración exterior (visible) de dicha figura, sí que cabe deducir de las pocas resoluciones en las que el Tribunal Constitucional se ha visto confrontado con el problema de la limitación de la apariencia exterior de la persona que se trata de una conducta (limitable) enmarcada en la protección del derecho a la propia imagen ${ }^{63}$, extremo que sí ha sido expresamente afirmado por la jurisdicción ordinaria ${ }^{64}$.

62 En este mismo sentido de considerar al velo islámico un símbolo religioso, se ha expresado el Bundesverfassungsgericht alemán en su sentencia Ludin, BVerfGE 108, 282, 299. Dos acercamientos contrapuestos a la definición de símbolo religioso, el primero más subjetivo y el segundo más objetivo, aplicables al velo integral islámico se pueden ver respectivamente en ALÁEZ CORRAL, B., «Símbolos religiosos y derechos fundamentales en la relación escolar», ob. cit., pág. 97-100 y MELÉNDEZ VALDÉS NAVAS, M., «Reflexiones jurídicas entorno a los símbolos religiosos», RGDCDEE, n² 24, 2010, pág. 6.

63 Así, en la STC 170/1987, de 30 de octubre, el TC da por buena la prohibición de llevar barba impuesta al barman de un hotel, porque la decisión personal sobre la apariencia física puede ser limitada en virtud de las relaciones laborales libremente asumidas mediante un contrato de trabajo, aceptando con ello que se trata de una facultad del derecho a la propia imagen que puede ser limitada; y en la STC 84/2006, de 27 de marzo, el Tribunal Constitucional declara extinguido el recurso de amparo interpuesto por los representantes sindicales de las azafatas del AVE, que se quejaban de injerencia en su derecho a la propia imagen por obligarles a llevar falda en su trabajo, al haberse satisfecho extraprocesalmente la pretensión, asumiendo con ello también indirectamente que la facultad de autodeterminar la configuración exterior de la persona formaba parte del objeto del derecho fundamental invocado en el recurso (y satisfecho extraprocesalmente).

64 En este mismo sentido, el Tribunal Supremo en su Sentencia de 17 de septiembre de 2007 (Sala 1ª), FJ. $1.3^{\circ}$, expresamente ha dicho que el derecho a la propia imagen «atribuye a su titular un derecho a determinar sus rasgos físicos personales y característicos» 


\section{b) Limitabilidad del uso velo islámico integral en los espacios públicos}

Aunque se afirme la abstracta protección del uso del velo integral por los derechos a la libertad religiosa o a la propia imagen, el ejercicio de esos derechos no es ilimitado, sino que pueden ser objeto de limitación con respecto a los derechos fundamentales de los demás y a otros bienes o valores también constitucionalmente garantizados, así como en el caso de las manifestaciones de la libertad religiosa con respecto al orden público protegido por la ley (art. 16.1 CE). Ello no quiere decir que la mayoría social pueda decidir libremente cuándo y qué límites impone a aquellos derechos, sino que, por imperativo constitucional, los mismos tienen que perseguir un interés general constitucionalmente legítimo, es decir, tienen que estar previstos expresamente en una norma constitucional o derivarse implícitamente de la garantía de otros derechos o bienes constitucionales ${ }^{65}$. Así, por ejemplo, en el caso de la prohibición de ciertas vestimentas en la escuela, como muy bien pone de relieve el Reglamento de Régimen interior del Instituto de Enseñanza Secundaria de Pozuelo, la limitación de la libertad religiosa/propia imagen de los alumnos que pretenden asistir a clase con velo islámico podría derivarse de la garantía del derecho a la educación, evitando las distracciones causadas por ciertas vestimentas. Ahora bien, salvo que se quiera caer en el absurdo de una sociedad orwelliana, sensorial y emocionalmente ataráxica, no parece que por sí mismo cualquier velo islámico (integral o no), o cualquier otro símbolo religioso, provoque por sí mismo una distracción de la atención de los alumnos que no pueda en muchos casos (como en los del velo islámico no integral) ser positivamente reconducida, con la adecuada intervención docente, hacia el pluralismo democrático al que debería estar orientada la educación por expreso mandato constitucional (art. 27.2 CE).

En otras palabras, constitucionalmente no se puede afirmar que los poderes públicos estén habilitados para fijar limites las conductas iusfundamentales de los ciudadanos en aras de la paz social, con tal de que sean generales y aplicables a todo el mundo sin distinción. Cuando se trata de la limitación de derechos fundamentales, las Constituciones democráticas, en particular la española, no son equidistantes respecto del conflicto entre mayoría y minoría, sino que se interponen directamente en favor de la minoría que ejerce sus derechos en el espacio público, limitando la capacidad de actuación del poder público y sometiendo su poder para limitar/delimitar esos derechos a estrictas exigencias formales - los límites deben establecerse por norma con rango de Ley de forma cierta y clara- y materiales - los límites deben establecerse sólo cuando sea necesario en una sociedad democrática para proteger ciertos bienes o derechos de rango constitucional, y deben aplicarse proporcionadamente ${ }^{66}$ —. De estas garantías formales y materiales, nos vamos a ocupar únicamente de la exigencia del rango legal de la norma que pretenda la limitación del uso del velo integral en los espacios públicos, entre las garantías formales, y de la necesidad de que exista una finalidad constitucionalmente legítima que fundamente el establecimiento de esa prohibición, entre las garantías materiales, puesto que son las dos que se utilizan con mayor fuerza para cuestionar la legitimidad constitucional de las prohibiciones del uso del velo islámico integral.

65 Cfr. la STC 292/2000, de 30 de noviembre, FJ 11º , la STC 14/2003, de 30 de enero, FJ $9^{\circ}$.

66 Sobre estos límites a los límites de los derechos fundamentales y sobre la discutible aplicabilidad del principio de proporcionalidad al legislador, cfr. Villaverde Menéndez, Ángel, Los límites a los derechos fundamentales, ob. cit., págs. 133-149. 


\section{c) El necesario rango legal de la norma limitativa del uso del velo islámico integral}

Por lo que refiere a las garantías de carácter formal, la principal es la exigencia de que la regulación material que limite o regule el ejercicio de un derecho fundamental de los regulados en el Capítulo $2^{\circ}$ del Título I de la CE posea rango legal ${ }^{67}$. En efecto, la limitación de la libertad religiosa o del derecho a la propia imagen, en la medida que se trata de un elemento esencial de los derechos recogidos en la Sección $1^{\mathrm{a}}$, Cap. $2^{\circ}$, Tit. I $\mathrm{CE}$, requeriría una regulación por Ley orgánica ${ }^{68}$, por lo que, en principio, tendría que ser la Ley Orgánica de libertad religiosa, o la futura reforma de la misma, la que estableciese los supuestos en los que el uso del velo islámico (integral o no) en tanto manifestación de la libertad religiosa pueden ser restringidos para la protección de bienes o derechos de rango constitucional. Pero, incluso aunque se aceptase que la prohibición del uso del velo islámico en ciertos espacios públicos no conlleva en sí misma una reducción del haz de facultades iusfundamentales protegidas por la libertad religiosa/la propia imagen, es decir, una limitación de dichos derechos, sino únicamente una determinación del tiempo, espacio y modo en que se pueden realizar la conducta iusfundamental consistente en llevar el velo islámico, excluyéndolo, por ejemplo, en aquellos casos en los que la comunicación requiere el máximo contacto gestual o visual posible, o la adecuada identificación de la persona para el acceso a un servicio o un edificio público, se estaría aún ante un caso de regulación del ejercicio del derecho fundamental, lo que conforme al art. 53.1 CE ha de hacerse por Ley ${ }^{69}$ del Estado o de las Comunidades Autónomas ${ }^{70}$. De ahí que la flexible interpretación del TEDH respecto al concepto «Ley» limitativa de la libre manifestación de las creencias, que incluye tanto las normas aprobadas por el Parlamento como las disposiciones reglamentarias de los Gobiernos de los Estados, sea un estándar común convencional que no alcanza el mínimo de garantía formal previsto por la Constitución, siendo de aplicación por tanto este último.

En base a lo anterior, hay que preguntarse por la conformidad con estas garantías constitucionales formales de disposiciones reglamentarias municipales como las modificaciones de las ordenanzas municipales que prohíben el acceso a edificios o instalaciones municipales portando un velo integral, o los Reglamentos de Régimen Interno de Centros escolares públicos que prohíben cualquier tipo de velo o prenda que cubra la cabeza, pues podrían carecer del adecuado rango legal para limitar/regular el ejercicio de la libertad religiosa y/o la propia imagen. Ejemplarmente ya se vio cómo esa falta de cobertura legal llevó al Consejo de Estado Italiano a declarar la ilegalidad de los Decretos municipales prohibitivos del velo integral islámico ${ }^{71}$, y al Bundesverfassungsgericht alemán a amparar a la profesora Ludin, expulsada de la función pública, sin la adecuada cobertura legal, por portar un $\mathrm{Hijab}^{72}$. Sin ánimo exhaustivo, veamos seguidamente si cumplen con esta garantía formal algunas de las disposiciones reglamentarias en las que se plasman, o

67 STC 49/1999, de 5 de abril, FJ $4^{\circ}$.

68 Cfr. STC 173/1998, de 23 de julio, FJ $8^{\circ}$.

69 Cfr., entre muchas, la STC 292/2000, de 30 de noviembre, FJ $11^{\circ}$ y la STC 53/2002, de 27 de febrero, $\mathrm{FJ} 12^{\circ}$.

70 STC 133/2006, de 27 de abril, FFJJ $4^{\circ}-5^{\circ}$.

71 Sentencia del Consejo de Estado italiano de 19 de junio de 2008.

72 BVerfGE 108, 282. 
de las que se deducen, prohibiciones de uso del velo islámico integral en los espacios públicos.

La habilitación legal de las ordenanzas municipales españolas que regulan las condiciones de acceso a los edificios e instalaciones municipales se puede ver, con carácter general, además de en la legislación sectorial del Estado o la respectiva Comunidad autónoma, en los art. 4.1 y 84.1.a) de la Ley 7/1985, de 2 de abril reguladora de las bases de régimen local (LBRL), que permiten al Municipio intervenir la actividad de los ciudadanos en el ámbito de sus competencias, algunas de las cuales son, conforme al art. 25.2.a) y c) LBRL, la seguridad en lugares públicos y la protección civil; y, por lo que respecta a la tipificación de las infracciones y sanciones en caso de contravención de las prohibiciones contenidas en las Ordenanzas, dicha habilitación legal se encuentra en los arts. 139 a 141 LBRL, conforme a los cuales, "para la adecuada ordenación de las relaciones de convivencia de interés local y del uso de sus servicios, equipamientos, infraestructuras, instalaciones y espacios públicos, los entes locales podrán, en defecto de normativa sectorial específica, establecer los tipos de las infracciones e imponer sanciones por el incumplimiento de deberes, prohibiciones o limitaciones contenidos en las correspondientes ordenanzas, de acuerdo con los criterios establecidos en los artículos siguientes». Aunque los perfiles con los que la legislación citada definen los términos en los que se pueden limitar las manifestaciones de las convicciones religiosas o el derecho a la configuración exterior de la imagen son abstractos, y se refieren más bien a la necesaria compatibilización del ejercicio de esos derechos fundamentales con la protección de los derechos de los demás o con bienes de rango constitucional, como el adecuado cumplimiento por parte de las entes locales de sus funciones, la protección del dominio público o la seguridad pública, lo cierto es que, conforme a la flexible interpretación que ha realizado la jurisprudencia constitucional del cumplimiento de la reserva de Ley en el caso del desarrollo de las materias reservadas por parte de las ordenanzas municipales ${ }^{73}$, basta que en la Ley se fijen unos criterios mínimos orientativos de la antijuridicidad de la conducta tipificada o prohibida en la ordenanza municipal, y de las clases sanciones impuestas $^{74}$, para considerar formalmente cumplido el requisito de la reserva de ley, lo que sucede, en mi opinión, con estas Ordenanzas.

Más sencillo resulta justificar formalmente las limitaciones al uso del velo islámico impuestas por los Reglamentos de Régimen interior de los centros escolares públicos, aplicadas de momento al velo no integral, pero extensibles al velo integral. Aquí, operan como suficiente regulación legal directa del ejercicio de los derechos fundamentales, o incluso de sus limitaciones, los deberes que impone el art. 6.4.b),e),f) y g) LODE a los alumnos, entre los que se encuentran: «b) Participar en las actividades formativas y, especialmente, en las escolares y complementarias»; «e) Participar y colaborar en la mejora de la convivencia escolar y en la consecución de un adecuado clima

73 Ya en la STC 233/1999, de 16 de diciembre, FFJJ $10^{\circ}$ y $18^{\circ}$, el Tribunal Constitucional había flexibilizado el concepto de reserva de ley tributaria en relación con las ordenanzas de las haciendas locales, sobre la base del carácter representativo de los órganos que las aprueban (Pleno del Ayuntamiento) y de la necesidad de reservar un ámbito de normación propio a los entes locales para respetar la garantía constitucional de la autonomía local prevista en el art. 137 CE.

74 Cfr. STC 132/2001, de 8 de junio, FJ $6^{\circ}$. 
de estudio en el centro, respetando el derecho de sus compañeros a la educación y la autoridad y orientaciones del profesorado»; «f) Respetar la libertad de conciencia, las convicciones religiosas y morales, y la dignidad, integridad e intimidad de todos los miembros de la comunidad educativa»; «g) Respetar las normas de organización, convivencia y disciplina del centro educativo» (la cursiva es nuestra) ${ }^{75}$. Las disposiciones reglamentarias, podrán, por tanto, concretar en detalle dichos deberes, contando con la debida cobertura legal mínima en la LODE

Por lo que se refiere a la regulación legal de las limitaciones al uso del velo islámico por parte de los profesores, algo que aún no ha generado polémica judicial en nuestro país, el art. 52 de la reciente Ley 7/2007, de 12 de abril, reguladora del Estatuto básico del empleado público, dispone que «los empleados públicos deberán desempeñar con diligencia las tareas que tengan asignadas y velar por los intereses generales con sujeción y observancia de la Constitución y del resto del ordenamiento jurídico, y deberán actuar con arreglo a los siguientes principios: objetividad, integridad, neutralidad, responsabilidad, imparcialidad, confidencialidad, dedicación al servicio público, transparencia, ejemplaridad, austeridad, accesibilidad, eficacia, honradez, promoción del entorno cultural y medioambiental, y respeto a la igualdad entre mujeres y hombres, que inspiran el Código de Conducta de los empleados públicos configurado por los principios éticos y de conducta regulados en los artículos siguientes» (la cursiva es nuestra). Y por su parte el art. 18 LODE establece respecto de los docentes de los centros escolares públicos que desempeñarán sus funciones «con sujeción a los principios constitucionales, garantía de neutralidad ideológica y respeto de las opciones religiosas y morales a que hace referencia el artículo 27.3 de la Constitución», así como que la administración educativa competente y, en todo caso, los órganos de Gobierno del centro docente «velarán por la efectiva realización de los fines de la actividad educativa, la mejora de la calidad de la enseñanza y el cumplimiento de lo dispuesto en el apartado anterior de este artículo» (la cursiva es nuestra). De unos y otros preceptos se deducen los derechos, bienes y valores de rango constitucional que operan como límites a las libertades (en este caso religiosa y a la propia imagen) de los docentes durante el desarrollo de sus funciones, en base a los cuales cabría dictar disposiciones reglamentarias prohibitivas del velo islámico integral, en la medida en que se demuestre la pérdida de neutralidad del docente ${ }^{76}$, un obstáculo para la mejor comunicación entre alumno y profesor ${ }^{77}$, un signo de despersonalización y discriminación de la mujer, que puede ser malinterpretado sobre todo por los alumnos más pequeños.

\section{Finalidades constitucionalmente legítimas para limitar el uso del velo} islámico integral en los espacios públicos

75 Que casi se limitan a reiterar los arts. 35 y 36 del Real Decreto 732/1995, de 5 de mayo, por el que se establecen los derechos y deberes de los alumnos y las normas de convivencia en los centros.

76 Como prevén las Leyes alemanas de educación de algunos Estados federados.

77 Tal y como puso de relieve la Sentencia del Tribunal de Apelación de Trabajo, de 30 de marzo de 2007, Azmi v Kirklees Metropolitan Borough Council [2007] UKEAT 0009_07_3003. 
Una vez analizadas las condiciones orgánico-procedimentales dentro de las cuales es posible que se limiten los derechos fundamentales involucrados con el uso del velo islámico integral, la cuestión más polémica de todas, pues de ella depende la licitud constitucional de una prohibición general de su uso en los espacios públicos, es la de cuáles sean las condiciones materiales de dicha limitación. Además de la genérica exigencia de que los límites respeten el contenido esencial del derecho fundamental, que impone el art. 53.1 CE, es decir, que no hagan irreconocible o impracticable en todo caso la garantía de libertad que contiene el derecho fundamental ${ }^{78}$, ya se indicó antes que no cabe dicha limitación de la libertad religiosa/propia imagen y, por tanto, la prohibición del uso del velo islámico integral en los espacios públicos, para perseguir cualesquiera finalidades o intereses generales.

De un lado, el art. 9 CEDH prevé como finalidades legítimas para limitar la libre manifestación de las creencias — pues no contempla como tal el derecho a la propia imagen- que la medida sea necesaria en una sociedad democrática para «la seguridad pública, la protección del orden, de la salud o de la moral públicas, o la protección de los derechos o las libertades de los demás» (la cursiva es nuestra). Aunque conforme al art. 10.2 CE, los Tratados internacionales sobre derechos fundamentales, como el CEDH, tienen valor interpretativo del alcance de los derechos garantizados en la CE de 1978, hay que considerar las finalidades antes mencionadas en consonancia con el marco de principios y valores previstos en la CE de 1978. A tenor de los mismos, tal y como cabe deducir de la jurisprudencia constitucional ${ }^{79}$, las limitaciones de ambos derechos sólo las puede establecer la Ley para concretar la protección de otros derechos fundamentales o bienes de rango constitucional, así como, en el caso de la libertad religiosa, para proteger el orden público (art. 16.1 CE), del que forman parte, según el art. 3 LOLR, la seguridad pública, la salud pública y la moral pública ${ }^{80}$. En este sentido, en el caso de las prohibiciones municipales de acceso a ciertos espacios o edificios públicos, como la que impone la Ordenanza municipal de Lleida de 2010, una interpretación constitucionalmente adecuada de los arts. 139 y 140 LBRL exige entender, en relación con las finalidades a las que sirven las infracciones locales en ellos previstas, que el daño a los bienes públicos — municipales — se refiere a la protección del dominio público (art. $132 \mathrm{CE}$ ), la perturbación de la tranquilidad solo es legítima cuando suponga la protección del orden público (art. 16.1 CE) y los derechos legítimos — de otras personas — han de ser derechos de rango constitucional, no bastando el interés socialmente mayoritario en nuestra cultura - OCcidental - en que no se oculte el rostro de las personas durante la realización de actividades cotidianas para que de la intranquilidad que ellos genere se produzca una perturbación del orden público constitucionalmente tutelado ${ }^{81}$. Los derechos fundamentales

78 Véase, por muchas, la STC 292/2000, de 30 de noviembre, FJ $11^{\circ}$.

79 Cfr. STC 37/1989, de 15 de febrero, FJ 7; STC 292/2000, de 30 de noviembre, FJ 11º; STC 14/2003, de 30 de enero, FJ $9^{\circ}$.

80 Una concreción del indeterminado concepto jurídico de «orden público» que además de vinculante es necesaria para la maximización del disfrute del derecho fundamental a la libertad religiosa. Sobre ello, cfr. PORRAS RAMÍREZ, J.M., Libertad religiosa, laicidad y cooperación con las confesiones en el Estado democrático de derecho, Thomson-Civitas, Madrid, 2006,. págs. 90-91.

81 Como, sin embargo, sostiene la STSJ de Cataluña, de 7 de junio de 2011, FJ $2^{\circ}$, aunque finalmente tenga que echar mano también de la seguridad pública como elemento del orden público limitativo de las manifestaciones de la libertad religiosa. 
protegen al individuo, a la minoría, no solo cuando o inquietan a la mayoría, sino también cuando producen esa inquietud, molestia o desasosiego en la sociedad, siempre y cuando su ejercicio no traspase los limites constitucionalmente establecidos ${ }^{82}$.

De igual manera, ya desde muy temprano el Tribunal Constitucional ha identificado restrictivamente la moral pública con un mínimo ético acogido por el derecho ${ }^{83}$, lo que sin duda remite a los valores y principios constitucionales, y la seguridad pública con la protección de personas y bienes, así como con la tranquilidad u orden ciudadano, garantizadas predominante por las organizaciones y los medios instrumentales, en especial los cuerpos de seguridad, a que se refiere el art. $104 \mathrm{CE}^{84}$, es decir, con la seguridad ciudadana o con la protección civil ${ }^{85}$. Por ello, se puede decir, en atención a los concretos efectos que tiene el uso del velo integral en los espacios públicos — que, en principio no parece que puedan afectar a la salud pública-, que las finalidades constitucionalmente legítimas para justificar la limitación del uso del velo islámico, se reducen a: la protección de la dignidad de la persona (mujer) y la igualdad de género a ella asociada, que sin duda pueden también vincularse a ese mínimo ético consustancial a la moral pública, la protección de la seguridad pública, en tanto elemento del orden público (material) definido por la Ley, la protección de los derechos fundamentales de los demás, que se ven afectados por el uso del velo integral en ciertas relaciones públicas, y el correcto funcionamiento de las instituciones y los servicios públicos.

De otro lado, además, la supremacía del texto constitucional escrito, que proclama el art. 9.1 $\mathrm{CE}^{86}$, la inexistencia de un haz de valores supra-positivos sustraídos a la reforma constitucional ${ }^{87}$, y sobre todo, la profusión y detalle con los que nuestra CE de 1978 recoge tanto los derechos fundamentales garantizados como sus límites y concretas técnicas de garantía, hacen incompatible con nuestro sistema constitucional apelar a la protección de un orden público inmaterial, como en Francia, para fundamentar la general prohibición del velo integral islámico en todo espacio público, al menos si tal orden público inmaterial se refiere a «un conjunto de exigencias mínimas de la vida en sociedad» distintas de las juridificadas como límites constitucionales de los derechos implicados en el uso del velo islámico integral. Reconocer carácter vinculante como límites de unas libertades iusfundamentales a bienes o valores meta-positivos que carecen de apoyatura expresa en el texto constitucional, bien contradiría el carácter supremo del texto constitucional, o bien, en caso de coincidir los mismos con bienes o derechos constitucionalizados — como por ejemplo, el respeto a la dignidad de la persona, los derechos de los demás o la ley, fundamento del orden político y de la paz social—, sería redundante y disfuncional, pues tendrían carácter jurídicamente vinculante con la concreta configuración que les haya dado el texto constitucional.

82 Aplicando a las manifestaciones de la libertad religiosa lo dicho por la STC 235/2007, de 7 de noviembre, $\mathrm{FJ}^{\circ}{ }^{\circ}$ en relación con la libertad de expresión: «la libertad de expresión comprende la libertad de crítica aún cuando la misma sea desabrida y pueda molestar, inquietar o disgustar a quien se dirige, pues así lo requieren el pluralismo, la tolerancia y el espíritu de apertura, sin los cuales no existe sociedad democrática».

83 STC 62/1982, de 15 de octubre, FJ $3^{\circ}$.

84 STC 33/1982, de 8 de junio, FJ 5º y STC 59/1985, de 6 de mayo, FJ $2^{\circ}$.

85 STC 25/2004, de 26 de febrero, FJ $6^{\circ}$.

86 Cfr. Declaración del Tribunal Constitucional 1/2004, de 13 de diciembre, FJ $4^{\circ}$.

87 Por todas, STC 48/2003, de 12 de marzo FJ $7^{\circ}$, y STC 103/2008, de 11 de septiembre, FJ $4^{\circ}$. 
Como se verá a continuación brevemente, ni la protección de la dignidad de la mujer o la seguridad pública, ni la tutela de los derechos fundamentales de los demás o el correcto funcionamiento de los servicios públicos, son por sí solos en nuestro sistema constitucional finalidades constitucionalmente legitimadoras de una prohibición general del uso del velo integral islámico en todo espacio público. Todo lo más, los segundos permitirán concretas prohibiciones sectoriales, que, no obstante, están sujetas en su aplicación por parte de las distintas administraciones y órganos jurisdiccionales al respeto del principio de proporcionalidad, y por tanto solo deberán operar cuando la prohibición sea una medida adecuada, necesaria y proporcionada para alcanzar las finalidades constitucionalmente legítimas ${ }^{88}$, máxime cuando, como se ha visto, las prohibiciones del uso del velo integral en España, aunque tienen base legal, aparecen concretadas en normas reglamentarias y no cabe entender que el legislador haya formulado por sí mismo con carácter general este juicio de proporcionalidad.

\section{a) La dignidad de la persona (mujer) y la seguridad pública}

Como primera - y principal— justificación material de la prohibición general del velo islámico integral en los espacios públicos, se suele invocar que aquél es un símbolo de dominación machista, contrario a la dignidad de la persona (mujer) y a la igualdad de género, que el Estado tiene ex arts. 9.2 y 10.1 CE la obligación de proteger. Sin negar que, efectivamente, el velo islámico integral pueda ser interpretado socialmente como un instrumento de aislamiento, discriminación y denigración de la dignidad de la mujer, las posibilidades de que la dignidad de la mujer y la igualdad de género operen como un bien constitucional delimitador de la libertad religiosa o la propia imagen de la mujer que pretende portar el velo islámico integral en público son realmente reducidas.

En efecto, dejando a un lado el hecho de que en nuestro sistema constitucional la dignidad de la persona no ha sido reconocida por el Tribunal Constitucional como un derecho fundamental autónomo ${ }^{89}$, sino como un valor jurídico fundamenta que refleja algunos de los derechos derechos fundamentales reconocidos en la $\mathrm{CE}^{90}$, un primer problema que aparece es que pretender aplicar esta finalidad constitucionalmente legitima a los casos en los que la mujer lleva voluntariamente el velo presupone una construcción de la dignidad de la persona y del principio de igualdad de género alejados de la configuración individualista que les ha dado la CE de 1978 y basados —quizás inconscientemente- en la antidemocrática idea de «todo para la mujer pero sin la mujer». Como muy bien ha puesto de relieve el Consejo de Estado francés en su informe de 25 de marzo de 2010, y se desprende de la jurisprudencia europea ${ }^{91}$, no cabe construir la dignidad humana al margen de la valoración de esa dignidad que lleva a cabo la propia mujer con el libre ejercicio de sus derechos fundamentales. Es decir, que si es o no indigno para las mujeres musulmanas llevar el velo, es a ellas a quien primero compete valorar en el ejercicio de sus libertades fundamentales, y no a la mayoría

88 Véase por muchas, la STC 169/2001, de 16 de julio, FJ $9^{\circ}$.

89 Cfr. STC 120/1990, de 27 de junio, FJ $4^{\circ}$.

90 Cfr. STC 53/1985, de 11 de abril, FJ $2^{\circ}$.

91 Cfr. STEDH de 17 de febrero de 2005, Caso K.A. y A.D. contra Bélgica. 
social con su valoración cultural paternalista ${ }^{92}$, salvo que se pudiese demostrar objetivamente una relación de causa efecto entre dicho mensaje machista e indigno para la mujer y un concreto empeoramiento de las condiciones de ejercicio de sus derechos fundamentales por parte del colectivo de mujeres musulmanas ${ }^{93}$, al que contribuirían las mujeres portadoras del velo integral. Y este es un argumento muy poderoso en contra de la pretensión del Estado de prohibir con carácter general el velo integral islámico en los espacios públicos por su carácter indigno para quienes lo portan, o para el grupo al que pertenecen,. Vivimos en una democracia de individuos y de los grupos en los que se integra, no en una democracia de grupos que se sirven de los individuos para lograr sus fines grupales. No en vano, tanto el art. 9.2CE, como el art. 10.1 CE, se refieren a la «...libertad e igualdad de los individuos y de los grupos en los que se integra...» y a la «dignidad de la persona» (la cursiva es nuestra), anteponiendo a ésta en singular sobre el colectivo, al que se protege también para proteger a la persona individual.

Se podrá decir, claro está, que la mujer musulmana que porta el velo integral está privada de auténtica autonomía de voluntad para decidir libremente debido a sus condicionantes religioso-culturales y familiares. Pero, aun aceptando que esto pudiera ser así en una mayoría de los casos, se estaría ante otro problema, el de la violencia o desigualdad de género en la familia y/o en la sociedad, que no solo afecta, por cierto, a las mujeres musulmanas sino también —aunque en menor medida- a otras mujeres occidentales, sobre todo desde la perspectiva de la resistencia de muchos padres a tolerar la libre formación de las conciencias de las personas que se encuentran bajo su influencia o cuidado (en especial los hijos) y a ignorar la progresiva capacidad constitucional de éstas para ejercer sus derechos fundamentales por sí mismas a medida que aumenta su grado e madurez ${ }^{94}$. Es más, en la cultura social dominante también existen multitud de pautas de conducta machista, asumidas voluntariamente por las mujeres occidentales, fruto de una cultura tradicional machista trasmitida de padres/madres a hijos/hijas e imbricadas en la sociedad, que van desde la representación visual del cuerpo femenino predominantemente como un objeto sexual, hasta el rol de la maternidad en la realización personal de la mujer. Para evitar cualquiera de estas desigualdades de género, contrarias a la dignidad de la mujer, el Estado dispone de otros instrumentos más eficaces que la limitación arbitraria e ilegítima de los derechos fundamentales de la mujer, como, por ejemplo, la supervisión y garantía de que padres o esposos respetan — también en el interior de las relaciones familiares - la libertad de conciencia de sus hijas o esposas, y no las adoctrinan en sus propias convicciones religiosas o morales, aunque sean instrumentos más impopulares que afectan a casi todos los grupos sociales y reflejan las deficiencias ético-democráticas que casi todos aún padecemos en nuestra vida cotidiana.

92 En un sentido parecido respecto del Hijab, aunque diferenciándolo del velo islámico integral, cfr. REY MARTÍNEZ, F., El problema constitucional del Hijab, ob. cit., págs. 8-10.

93 Algunos estudios antropológico-sociales incluso demuestran, en relación con el Hijab, justamente lo contrario; cfr. MOUALHI, D., «Mujeres musulmanas: estereotipos occidentales versus realidad social», Papers, n60, 2000, págs. 297-299.

94 Sobre esto, cfr. ALÁEZ CORRAL, B.,, Minoría de edad y derechos fundamentales, Tecnos, Madrid, 2003 , págs. 128 ss. 
En este mismo orden de justificaciones de la prohibición general del velo islámico en los espacios públicos entra también, sobre todo tras la psicosis colectiva que ha desatado el terrorismo islamista desde el 11 de septiembre de 2001, la protección de la seguridad pública, mencionada por el art. 3 LOLR, en consonancia con el art. 9 del $\mathrm{CEDH}$, como un elemento del orden público limitativo de las manifestaciones de la libertad religiosa. Ya se ha dicho cómo, conforme a la jurisprudencia constitucional ${ }^{95}$, la misma debería interpretarse en el sentido de seguridad ciudadana en este contexto limitativo de la libertad religiosa, es decir, en el sentido de una seguridad que redunda en el beneficio de los ciudadanos y no de abstractos e inmateriales intereses de orden público. Lo cierto es que hasta el momento no se ha podido establecer de forma racionalmente fiable una correlación causa-efecto entre que las mujeres porten el velo integral islámico y que haya un mayor riesgo de que se cometan en nuestro país atentados terroristas u otras amenazas más leves para la seguridad pública ${ }^{96}$. Es más, el Tribunal Europeo de Derechos Humanos ha afirmado hace un año (Arslan contra Turquía) que el simple hecho de encontrarse en la vía pública un grupo de personas vestidas de una forma concreta (en este caso era un turbante, un «salvar» y una túnica negra) no constituye una amenaza para el orden público (en su versión de seguridad pública) o una coacción sobre los demás ${ }^{97}$. Y aunque esta sentencia declara la ilegalidad de la prohibición de un tipo concreto de vestimenta religiosa basada en el principio de laicidad y no en el orden público, sí puede servirnos de criterio orientador acerca de lo que el TEDH considera amenazador para la seguridad pública y qué no.

Es verdad que, en virtud de lo dispuesto en el art. 20 de la vigente Ley Orgánica 1/1992, de 21 de febrero, de protección de la seguridad ciudadana «los agentes de las Fuerzas y Cuerpos de Seguridad podrán requerir, en el ejercicio de sus funciones de indagación o prevención, la identificación de las personas y realizar las comprobaciones pertinentes en la vía pública o en el lugar donde se hubiere hecho el requerimiento, siempre que el conocimiento de la identidad de las personas requeridas fuere necesario para el ejercicio de las funciones de protección de la seguridad que a los agentes encomiendan la presente Ley y la Ley Orgánica de Fuerzas y Cuerpos de Seguridad» (la cursiva es nuestra), estándose, en los casos de resistencia o negativa infundada a identificarse o a realizar voluntariamente las comprobaciones o practicas de identificación, a lo dispuesto en el Código Penal y en la Ley de Enjuiciamiento Criminal ${ }^{98}$. Pero la posibilidad de esos controles no implica una prohibición general de cubrirse el rostro o hacer dificultosa la identificación, sino únicamente la obligación de descubrirse para la identificación cuando la persona sea requerida en un control de identidad necesario para el cumplimiento de las funciones que las leyes encomiendan a los cuerpos y fuerza de seguridad, y por tanto parciales prohibiciones de uso del velo islámico integral en ciertos contextos (controles de identidad) en los espacios públicos. En consonancia con esa finalidad identificadora, preventivamente protectora de la seguridad ciudadana, que le confiere el art. 10 de la Ley orgánica 1/1992 a los docu-

95 STC 33/1982, de 8 de junio, FJ 5º, y STC 59/1985, de 6 de mayo, FJ $2^{\circ}$.

96 En este mismo sentido, el Informe del Consejo de Estado francés de 23 de marzo de 2010.

97 STEDH de 23 de febrero de 2010 (Arslan y otros contra Turquía).

98 Respecto de este precepto y su interpretación constitucionalmente conforme de estas funciones de identificación para la seguridad ciudadana, véase la STC 341/1993, de 18 de noviembre, FFJJ $3^{\circ}-6^{\circ}$. 
mentos de identidad personal como el DNI y el Pasaporte, resulta también justificada desde un punto de vista constitucional la exigencia que se deduce del Real Decreto 896/2003, de 11 de julio, por el que se regula la expedición del pasaporte ordinario y se regulan sus características, y del Real Decreto 196/1976, de 6 de febrero, por el que se regula el Documento Nacional de Identidad, de que en las fotografías que se utilicen para ellos su titular aparezca con determinadas prendas que impidan su plena identificación ${ }^{99}$, aunque la misma conlleve indirectamente una prohibición sectorial del uso del velo islámico integral.

De igual modo, por lo que se refiere a la seguridad pública derivada del tráfico de vehículos a motor, tampoco resultaría inconstitucional la prohibición sectorial de utilizar velo islámico integral durante la conducción de un vehículo a motor, deducida del art. 11 del Real Decreto Legislativo 339/1990, de 2 de marzo, por el que se aprueba el texto articulado de la Ley de Seguridad Vial, que impone a los conductores la obligación de «estar en todo momento en condiciones de controlar sus vehículos», y para ello «mantener su propia libertad de movimientos, el campo necesario de visión y la atención permanente a la conducción...», capacidades que se pueden ver menoscabadas con prendas que cubren los ojos y/o reducen el ángulo de visión como el Burka o el Niqab.

\section{b) La protección de los derechos fundamentales de los demás y el correcto funcionamiento de las instituciones y los servicios públicos}

Por último, aparecen dos finalidades constitucionalmente legítimas que, por su propia naturaleza normativa, se presentan como idóneas para justificar, en ciertos casos, prohibiciones parciales del uso del velo integral, pero nunca para justificar prohibiciones generales. Tal es el caso de la protección de los derechos fundamentales de los demás (garantizados en el Cap. $2^{\circ}$ del Tít. I CE) y el correcto funcionamiento de los servicios públicos (educativo, sanitario, militar, del transporte, etc...) y de las instituciones públicas (nacionales, autonómicas o locales). Ni los derechos fundamentales de los demás pueden estar omnipresentes en todo espacio público, justificando así la prohibición general del uso del velo islámico integral, pues eso equivaldría a que fuesen derechos absolutos, y conforme a la jurisprudencia constitucional ningún derecho fundamental es ilimitado o absoluto, sino que todos se limitan recíprocamente ${ }^{100}$, ni las instituciones públicas y servicios públicos ocupan y regulan permanentemente todo el espacio público, pues, de hacerlo, dejarían también sin un ámbito de ejercicio fuera de la vida privada algunos derechos fundamentales, como la libertad religiosa, la libertad personal, el derecho de manifestación, etc..., que han sido garantizados expresamente en los arts. 16, 17 o 21 CE con vocación de que se ejerzan en el foro público.

En este sentido, las prohibiciones que, por ejemplo, se derivan de la legislación sobre la función pública o la actividad escolar, solo pueden ser parciales y están referidas al correcto desempeño de la función pública en general y de la función educativa en parti-

99 Según la interpretación constitucionalmente conforme que acertadamente propone para el tenor literal de dichos Reales Decretos CAÑAMARES ARRIBA, S., «El empleo de simbología religiosa en España», Boletín Mexicano de Derecho Comparado, n 116,2006, pág. 336.

100 Cfr. por todas, STC 2/1982, de 29 de enero, FJ $5^{\circ}$. 
cular. En ellas se combinan como finalidades constitucionalmente justificativas el correcto funcionamiento del servicio público de que se trate y la educación de los alumnos (art. 27 CE). Tanto ese derecho fundamental de los demás, como el correcto funcionamiento del servicio público educativo, se contraponen al uso del velo integral islámico por parte de los profesores y de los alumnos, no tanto por una falta de neutralidad de los primeros - que podrían mantenerse neutrales en el desarrollo de su actividad pedagógica-, cuanto por las distorsiones en el proceso de comunicación y aprendizaje entre profesor y alumno, que se derivan de la barrera a la comunicación gestual/visual que supone el velo integral de una profesora ${ }^{101}$ o de una alumna ${ }^{102}$. Además, profesores y alumnos de centros escolares públicos se encuentran en el ámbito educativo en una relación de sujeción especial, lo que implica una posibilidad de limitación de sus derechos fundamentales por parte del legislador más intensa, precisamente por la necesidad de que se satisfaga eficazmente la función educativa que se desarrolla en ese espacio público y que involucra personalmente a docentes y discentes.

De igual manera, aunque no se enmarquen en ninguna relación de sujeción especial, el uso y acceso de los ciudadanos a los edificios públicos municipales se encuentra condicionado por el correcto desenvolvimiento de los servicios públicos allí prestados, expresión del ejercicio por parte de los entes locales de las competencias que la LBRL les confiere en garantía de su autonomía local (art. $137 \mathrm{CE}$ ), por el eficiente funcionamiento de las administraciones públicas que con carácter general prescribe el art. $103 \mathrm{CE}$ o, en fin, por su competencia para tutelar los bienes integrantes del dominio público (art. $132 \mathrm{CE}$ ). Todas ellas son finalidades constitucionales materialmente justificativas de las prohibiciones de acceso a edificios o servicios de titularidad municipal que han previsto las ordenanzas municipales recientemente aprobadas en distintos Ayuntamientos. Tanto la identificabilidad de los usuarios de los servicios públicos municipales, como la prevención de la seguridad pública en el acceso a los edificios municipales, son dos medidas razonables para garantizar el correcto funcionamiento de los servicios públicos municipales y la eficacia de la administración municipal, por más que estemos acostumbrados a un dejado de funciones en este ámbito y a que apenas se controle quienes usan los servicios municipales sin ser población del respectivo municipio a los efectos del art. 15 LBRL, ni la identidad y las condiciones de seguridad de quienes acceden a los edificios públicos municipales. Mientras que el uso de la vía pública o del espacio público abierto en general es anónimo, el uso de los edificios municipales o de los servicios públicos municipales no lo es, y ello puede justificar sectorialmente esa limitación de la libertad religiosa.

Finalmente, las prohibiciones de uso del velo islámico por parte de abogados, testigos, y quizás también en el futuro de jueces y magistrados, que se deducen de las obligaciones legales (LOPJ y diversa legislación procesal) y reglamentarias (art. 37.1 del Real Decreto 658/2001, de 22 de junio, por el que se aprueba el Estatuto de la Abogacía, y art. 33 del Reglamento 2/2005, de 23 de noviembre, de Honores, Tratamiento y proto-

101 Respecto de la profesora, véase la Sentencia del Tribunal de Apelación de Trabajo, de 30 de marzo de 2007, Azmi v Kirklees Metropolitan Borough Council [2007] UKEAT 0009_07_3003.

102 Tal y como se hizo en Bonn en 2006, al amparo de los $\$ \$ 42$ y 53 de la Ley de educación, de 30 de marzo de 2004, del Land de Renania del Norte-Westfalia. 
colo en los Actos judiciales solemnes) y que pesan sobre aquéllos, están también justificadas constitucionalmente en la medida en que coadyuvan al correcto funcionamiento de la Administración de Justicia (art. 117 CE) y a la protección del derecho a la tutela judicial efectiva de los ciudadanos (art. $24 \mathrm{CE}$ ), lo que habría que apreciar en cada caso o situación concreta. En efecto, uno y otro bien constitucional se podrían ver comprometidos por la apariencia de parcialidad ideológica o religiosa, así como por la merma en sus capacidades cognitivas para la dirección del proceso y la emisión de una resolución que experimentarían las juezas o magistradas portadoras del velo islámico (integral o no) en la Sala. Pero también se verían comprometidos por la merma en la capacidad comunicativa con el órgano jurisdiccional y con las propias partes —incluido su defendido- que experimentarían las abogadas ataviadas con un velo integral, o en fin por la dificultad de valorar la veracidad del testimonio aportado en un procedimiento penal por una testigo ataviada con un velo islámico integral ${ }^{103}$, lo que además comprometería el derecho a la presunción de inocencia, que implica el derecho a no ser condenado sin suficientes pruebas de cargo. De ahí que en una relación de sujeción especial, como es la que se entabla con ocasión del ejercicio de la función jurisdiccional o de la colaboración con la Administración de Justicia, los participantes en la misma puedan ver limitada temporalmente de forma más intensa una de las facultades que forman parte de su libertad religiosa/derecho a la propia imagen, sin perjuicio, eso sí, de que los órganos jurisdiccionales o administrativos que deduzcan esa prohibición limitativa de las libertades constitucionales de quienes ejercen o colaboran con la función jurisdiccional la apliquen respetando el principio de proporcionalidad ${ }^{104}$.

$$
* * *
$$

TITLE: Some constitutional thoughts about the Islamic full veil ban in Europe.

ABSTRACT: This work deals critically with the islamic full veil ban in public spaces, that is starting to be adopted in some European countries and has found echo in some regulations of spanish municipalities. After a brief analysis of the general bans recently passed in Belgium and France and of the partial bans adopted at schools by other countries, like Germany, Italy or the UK, the article analises from a constitutional perspective, that includes the case-law of the European Court of Human Rights, the constitutionality of the recently established local bans in Spain. The author reaches the conclusion that according to the Sp. Const. 1978 an adequate interpretation of the limitations to the freedom of religion and right to the own image, involved when wearing an islamic full veil, would make unconstitutional a general ban of the full veil in each and every public space, but would constitutionally allow its partial ban regarding the access to municipal buildings or services or regarding teachers and pupils at public institutions of education, when these partial bans could be justified by constitutionally values like the safeguarding of public institutions or services, or like the protection of the fundamental rights of others.

103 Esta limitación del velo integral islámico por parte de los testigos solo debería aplicarse en los procedimientos penales, no en los civiles, puesto que en éstos la presencia del testigo no es obligatoria, y la falta de fiabilidad del testimonio que se deduce de la cobertura del rostro debería soportarla la parte que aporta un testigo revestido con velo integral. Sin embargo, en contra de que deba sufrir la libertad religiosa de la mujer con Niqab, y en favor de un equilibrio con una cierta limitación del derecho del acusado a un juicio justo, véase, Allen, Anita L, Veiled women in the american Courtroom: Is the Niqab a barrier to justice?, ob. cit., págs. 20-21.

104 Tal y como hizo el Tribunal Constitucional Federal alemán, por ejemplo, respecto de la prohibición del velo islámico no integral en su Sentencia de 27 de junio de 2006. 
RESUMEN: En este trabajo se analizan críticamente las probibiciones del uso del velo islámico integral en los espacios públicos que empiezan a proliferar en Europa y de las que empiezan a hacerse eco algunos Ayuntamientos españoles. Tras un somero análisis de las probibiciones generales por las que se han inclinado Bélgica y Francia, y de las probibiciones parciales que predominan en otros Estados, como Alemania, Italia o el Reino Unido, en ámbitos como el escolar se evalúa desde una perspectiva jurídico-constitucional, que incluye la jurisprudencia del Tribunal Europeo de Derechos Humanos, las probibiciones que empiezan a reclamarse y establecerse en España. El autor llega a la conclusión de que una interpretación dogmáticamente adecuada a la CE de 1978 de las limitaciones posibles a los derechos a la libertad religiosa y a la propia imagen, implicados con el uso del velo integral islámico, hace constitucionalmente ilícita una probibición general del mismo en todos los espacios públicos, pero permite justificar probibiciones parciales, como las recientemente adoptadas en algunos municipios españoles para el acceso a edificios o servicios municipales, o las impuestas a alumnos y docentes en centros escolares públicos, en la medida en que estén dirigidas a garantizar el correcto funcionamiento de las instituciones y los servicios públicos y/o a la protección de los derechos de los demás.

Keywords: Constitutional Law. Fundamental Rights, Freedom Of Religion, Establishment Clause, Own Image, Islamic Full Veil, Burka, Constitutional Comparative Law, European Union.

PALABRAs Clave: Derecho constitucional, derechos fundamentales, libertad religiosa, aconfesionalidad del estado, derecho a la propia imagen, velo integral, burka, derecho constitucional comparado, Unión Europea.

FECHA DE RECEPCIÓN: 25.01.2011. FeCHA DE ACEPTACIÓN: 29.07.2011.

UNED. Teoría y Realidad Constitucional, núm. 28, 2011, pp. 483-520. 
